Volume 9, Issue 2 (Summer 2017)

\title{
Ter Brugghen’s Saint Sebastian Tended by Irene
}

Valerie Hedquist

Valerie.Hedquist@mso.umt.edu

Recommended Citation:

Valerie Hedquist, "Ter Brugghen’s Saint Sebastian Tended by Irene," Journal of Historians of Netherlandish Art 9:2 (Summer 2017) DOI: 10.5092/jhna.2017.9.2.3

Available at https://jhna.org/articles/ter-brugghen-saint-sebastian-tended-irene/

Published by Historians of Netherlandish Art: https://hnanews.org/

Republication Guidelines: https://dev.jhna.org/republication-guidelines/

Notes: This PDF is provided for reference purposes only and may not contain all the functionality or features of the original, online publication. This PDF provides paragraph numbers as well as page numbers for citation purposes.

ISSN: 1949-9833 
JOURNAL OF HISTORIANS OF NETHERLANDISH ART

\title{
Ter Brugghen’s Saint Sebastian Tended by Irene
}

\author{
Valerie Hedquist
}

This article argues that Hendrick ter Brugghen included specific physical, environmental, and cultural allusions to contemporary attitudes about the plague's origins, symptoms, and remedies in his painting Saint Sebastian Tended by Irene. These references established a recognizable setting for the integration of approaches to healing from the past with those of the artist's own time. With this framework, ter Brugghen was also able to address the divergent religious beliefs of his multiconfessional community during a period of recurring epidemic outbreaks. The artist presented the plague-ravaged present as the setting for his depiction of the Christ-like figure of the martyred saint, whose body reveals signs of the dreaded disease. To this well-established Roman Catholic miracle-working intercessor and source of spiritual comfort, ter Brugghen added the post-Tridentine figure of the caregiver Irene, who provides comfort in a temporal charitable act. Her close physical contact with Saint Sebastian underscores her willingness to remain and heal, which corresponds closely to the position of contemporary Dutch religious and secular caregivers, especially orthodox Calvinists, who refused to flee during the recurring plague seasons.

Hendrick ter Brugghen's Saint Sebastian Tended by Irene, signed and dated 1625, portrays a haunting image of a failed execution from the early Christian past along with references to contemporary plague outbreaks (fig. 1). Having survived an initial attempt on his life by Roman archers, Saint Sebastian became closely associated with arrows, which reflected his worldly career as a professional soldier, his religious role as a militant defender of the new faith, and eventually his intercessory action as a martyr capable of healing the plague. Saint Sebastian, pierced with projecting shafts, was often represented with the Virgin Mary or as a solitary figure resembling Christ in thaumaturgic pictures that served as spiritual cures for the afflicted. In the late sixteenth century, the figure of Irene was restored to the religious narrative in order to encourage the community of the healthy to practice Christ-like charity toward the sick as an act of temporal care. Both the contemplative comfort offered by Saint Sebastian and the active intervention of Irene were urgently needed in the early seventeenth century, when the plague swept through Rome and Utrecht, where ter Brugghen (1588-1629) lived and worked.

In his striking painting, ter Brugghen conflated Roman Catholic and orthodox Calvinist beliefs in a scene that resonates with the past and present. Ter Brugghen acknowledged established Roman 


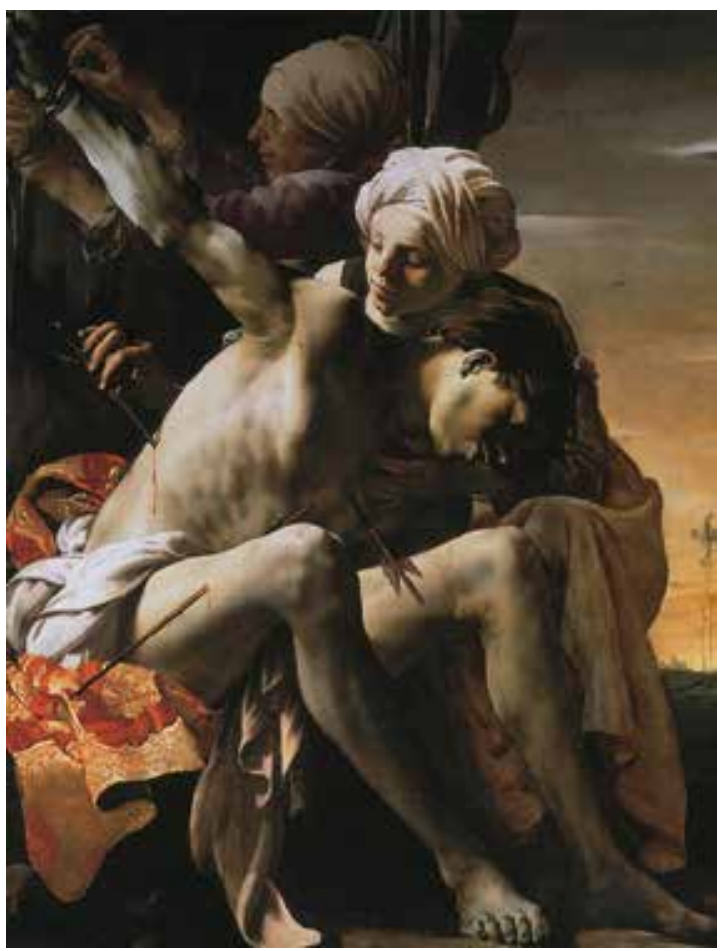

Fig. 1 Hendrick ter Brugghen, Saint Sebastian Tended by Irene, 1625 , oil on canvas, $149 \times 119.4 \mathrm{~cm}$. Oberlin, Ohio, Oberlin College, Allen Memorial Art Museum, R. T. Miller, Jr. Fund, 1953, inv. AMAM 1953.256 (artwork in the public domain)

Catholic pictorial and iconographic traditions by representing Saint Sebastian as a miraculous healer of the plague. In addition, he incorporated post-Tridentine modifications by including the figure of Irene, whose role as a secular healer shifted the religious narrative from the saint's death sentence to his unexpected recovery. The inventive depiction of the seated saint and his female rescuer at the scene of the foiled execution was enhanced by specific physical, environmental, and cultural allusions to prevailing seventeenth-century attitudes about the plague's origins, symptoms, and remedies. These previously unrecognized references situate the saint's suffering in the contemporary context of recurrent plague eruptions in Utrecht. This expanded analysis of ter Brugghen's depiction of Saint Sebastian and Irene also affirms the orthodox Calvinist position to remain in the community of sufferers and to avoid fleeing the epidemic. Identifying the intersection of tradition and innovation in this painting reveals ter Brugghen's sensitivity to the multiconfessional nature of his community, where diverse beliefs were practiced and proselytized.

The theme of Saint Sebastian originated in Italy, where a number of Utrecht painters traveled to study the celebrated artworks of classical antiquity, the Renaissance, and Caravaggio and his followers. As the first artist from this group to head south, ter Brugghen arrived in Rome in late 1607 or early 1608 and remained in the city until sometime in 1614, when he returned to Utrecht. ${ }^{1}$ He might have visited Rome a second time around $1620 .{ }^{2}$ Nevertheless, the artist left no documented artwork in Italy.

4 His contemporary, Dirck van Baburen (1595-1624), on the other hand, received both public and private commissions while in Italy. He lived there from about 1612 until the fall of 1620 or the winter of 1621, when he returned to Utrecht. ${ }^{3}$ The approximately nine paintings completed by van Baburen during his Italian period are far outnumbered by Gerrit van Honthorst's Roman works. Leaving for Italy around 1613, van Honthorst (1592-1656) famously achieved the nickname 
"Gerardo delle Notti" by the time he returned to Utrecht in $1620 .{ }^{4}$ Ten years after ter Brugghen's departure, Jan van Bijlert (1598-1671) left for Italy around 1617 and returned to Utrecht in $1624 .{ }^{5}$

These artists all depicted scenes of Saint Sebastian after returning from Italy. The impetus was likely their encounter with fellow citizens dying from the plague in Utrecht. Especially high mortality rates resulting from the disease were recorded during the period between 1613 and 1617, when ter Brugghen came home and van Bijlert left, and during the years 1624 and 1625, when ter Brugghen and his contemporaries produced the greatest number of images featuring the plague saint. ${ }^{6}$

The earliest work corresponding to these Utrecht outbreaks includes both Saint Sebastian and Irene and was painted sometime in the 1610s by the relatively unknown Cornelis de Beer (active 1616-1630), who entered the Utrecht painter's guild in 1616, the same year as ter Brugghen (fig. 2). ${ }^{7}$ Subsequently, Honthorst painted a solitary figure of Saint Sebastian in a work of ca. 1620 and van Baburen and his workshop completed horizontal compositional versions depicting Saint Sebastian and Irene during the particularly lethal plague seasons in Utrecht between 1623 and 1625 (fig. 3 and fig. 4). ${ }^{8}$ During this same period, van Bijlert painted a scene closely following van Baburen's horizontal prototype (fig. 5) and ter Brugghen painted the Oberlin canvas. ${ }^{9}$

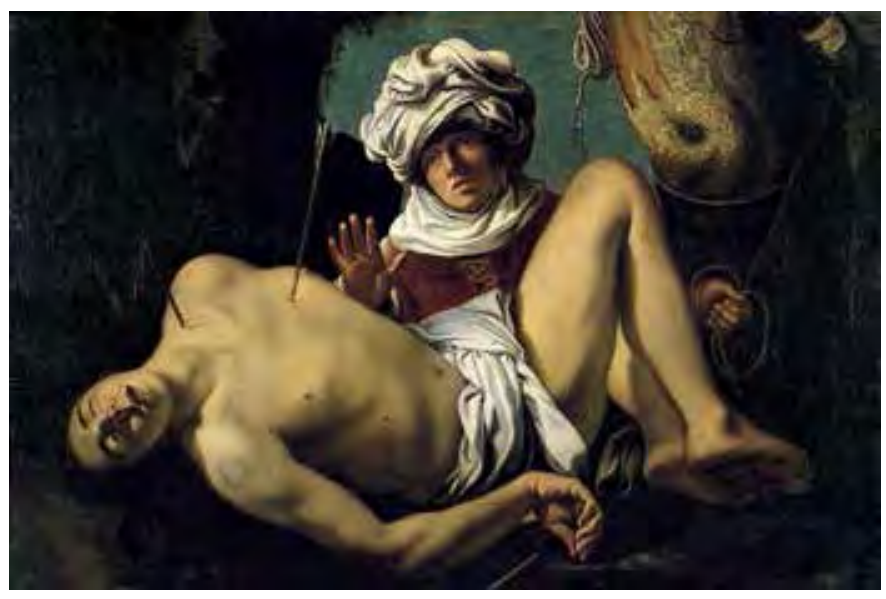

Fig. 2 Cornelis de Beer, Saint Sebastian Tended by Irene, 1610s, oil on canvas, $107 \mathrm{x}$ $147 \mathrm{~cm}$. Sold at Christie's London, Dec. 13, 1996, lot no. 257 (artwork in the public domain)

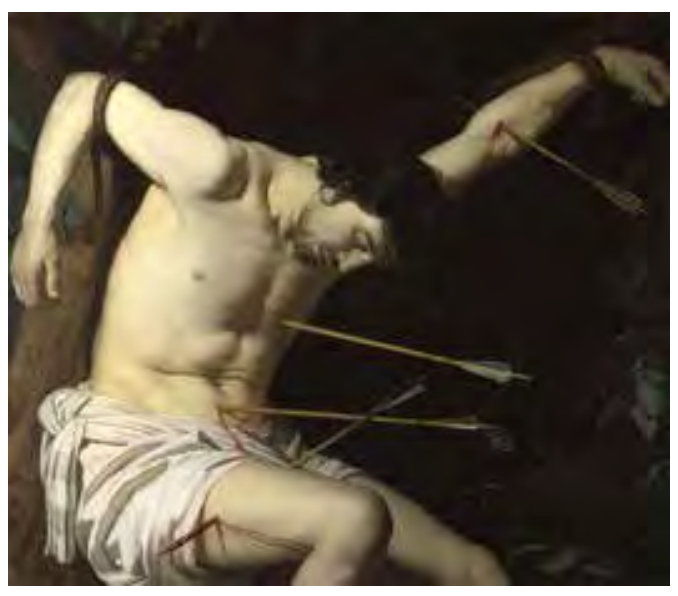

Fig. 3 Gerrit van Honthorst, Saint Sebastian, ca. 1623, oil on canvas, $101 \times 117 \mathrm{~cm}$. London, National Gallery, inv. NG4503 (artwork in the public domain; photo credit: @ The National Gallery, London)

Similarities in these depictions support the strong possibility that the artists were aware of each other's paintings and may have looked to the same pictorial source. It has been suggested that van Baburen and ter Brugghen shared a studio during the period when their versions were completed, and van Honthorst's depiction of the saint with an extended straight arm recurs in the paintings by van Baburen, van Bijlert, and ter Brugghen. ${ }^{10}$ In these instances, the seated or supported figure of the saint is presumably dead or dying and remains bound to the tree where his martyrdom was to occur. In contrast to the many depictions showing Saint Sebastian standing upright, the preferred choice of Italian artists, the paintings by the Utrecht artists present unusual 


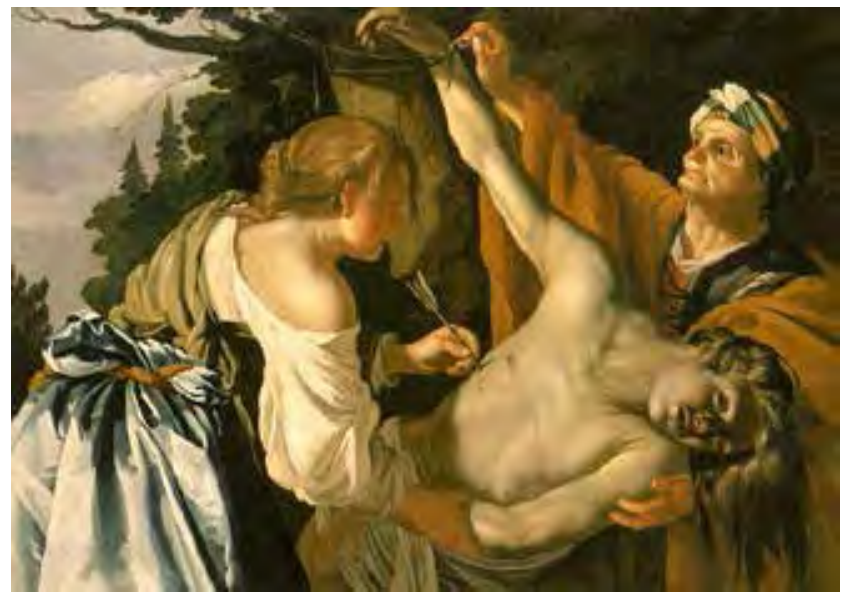

Fig. 4 Dirck van Baburen, Saint Sebastian Tended by Irene, ca. 1623-24, oil on canvas, 108.8 x $153.5 \mathrm{~cm}$. Hamburg, Kunsthalle, inv. 788 (artwork in the public domain)

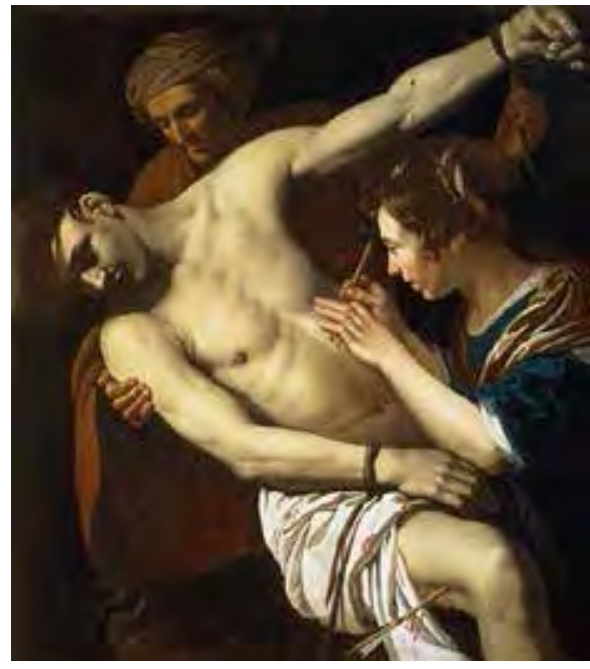

Fig. 5 Jan van Bijlert, Saint Sebastian Tended by Irene, 1624, oil on canvas, 113 x $100 \mathrm{~cm}$. Rohrau, Austria, Schloss Rohrau, Graf Harrach'sche Familiensammlung (artwork in the public domain)

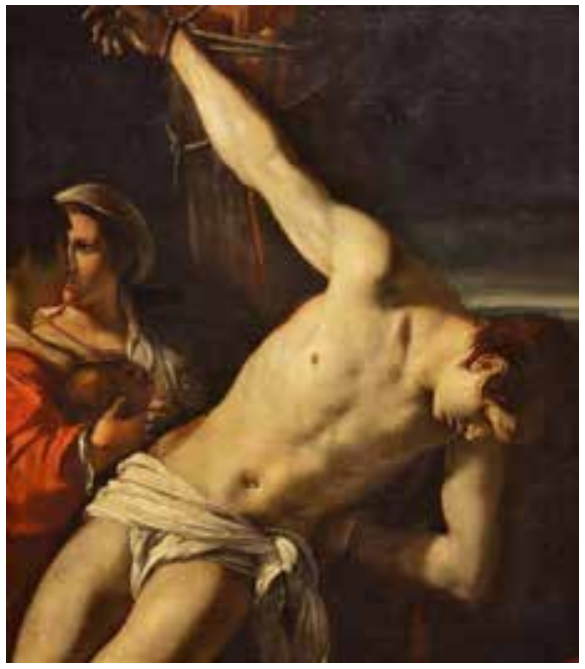

Fig. 6 Attributed to Angelo Caroselli, Saint Sebastian and Irene, first half of 17th century, oil on canvas, $119 \times 107 \mathrm{~cm}$. Moscow, State Pushkin Museum of Fine Arts, inv. 2686 (artwork in the public domain)

compositional alternatives evident in only a small number of extant Italian predecessors. For example, the position of the saint's body in one Italian painting is strikingly analogous to the Dutch depictions (fig. 6). ${ }^{11}$ This work has recently been attributed to Angelo Caroselli (15851652), whose religious and genre paintings strongly influenced the art of van Baburen and the other Utrecht painters living in Rome. ${ }^{12}$ Since the hagiographic texts and the representations and connotations of the saint, especially regarding his association with the plague, were conceived and refined in Italy, Caroselli's influence as a pictorial and iconographic source for the Utrecht contemporaries is persuasive. Ter Brugghen's painting, in particular, closely corresponds to Caroselli's version and shows a profound understanding of the Italian origins of Saint Sebastian's life and enduring significance.

\section{Italian Sources for Sebastian as a Plague Saint}

The earliest written account of the saint's life comes from a fifth-century source, the Passio Sancti Sebastiani. According to this biography, Sebastian was a favored captain in the Praetorian Guard 
of Emperor Diocletian around the year 300. His public support of Christians resulted in many conversions, and he continued to proselytize even when the emperor asked him to stop. As a result, Sebastian was ordered to be shot with arrows. So many of them passed into his body that the Passio records the victim looked "like a hedgehog." ${ }^{13}$ Sebastian miraculously survived and was cured by Irene in her home. In response to his ongoing proselytizing for Christianity, Sebastian was arrested a second time and beaten to death with clubs. His body was thrown into the city's sewer but was subsequently recovered and eventually buried in the catacombs along the Via Appia. ${ }^{14}$

9 The Passio does not connect Saint Sebastian with the plague. However, it does locate his burial next to Saints Peter and Paul, which led to his recognition, by the seventh century, as the third patron saint of the city of Rome. At about the same time, Saint Sebastian was first credited with ending plague epidemics in both Rome and Pavia. ${ }^{15}$ As Sheila Barker has persuasively argued, these early miracles were not the result of any specific antipestilential powers wielded by Saint Sebastian. Rather, they developed from the saint's close association with Saints Peter and Paul and with the miraculous power of his relics, especially his arm, which were brought from Rome to Pavia in 680. In fact, Barker argued that the emergence of a "direct cultic link" between Saint Sebastian and the plague only occurred with the publication of Jacobus da Voragine's Golden Legend from about $1260 .{ }^{16}$ Subsequently, Saint Sebastian was regarded as a particularly efficacious intercessor against the plague. ${ }^{17}$

10 Early depictions of Saint Sebastian resemble representations of Saints Peter and Paul, the other patron saints of Rome. For example, in a late seventh-century mosaic in San Pietro in Vincoli, Saint Sebastian appears as an old man with a white beard who is dressed in a ceremonial white tunic and holds a martyr's crown (fig. 7). By the tenth century Saint Sebastian's attempted execution appears in a narrative fresco cycle in the church of San Sebastiano on the Palatine Hill where the act allegedly occurred. ${ }^{18}$ At this point in the iconographic development, Saint Sebastian had no clear pictorial association with the plague. His depiction as a victim of Diocletian's archers simply underscored his role as a fellow soldier who defiantly defended the emerging early Christian church.

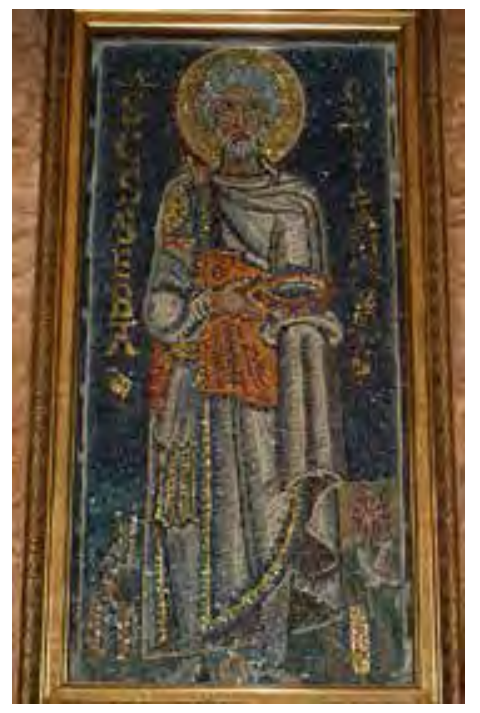

Fig. 7 Saint Sebastian, ca. 7th century, mosaic. Rome, San Pietro in Vincoli (artwork in the public domain) 
11 Not surprisingly, images directly linking Saint Sebastian to the plague emerged after the Golden Legenddisseminated the story of his healing powers and the disease devastated the city-states of Italy during the middle of the fourteenth century. In his altarpiece for the Duomo in Florence (1375-80), Giovanni del Biondo presented for the first time the visual association between the saint's martyrdom and his healing power ${ }^{19}$ (fig. 8). In a scene that closely resembles Christ's crucifixion, Giovanni's central panel shows the saint elevated above his executioners, while in the lower section of the flanking left wing, Saint Sebastian and the Virgin Mary intervene to end the plague in Pavia. Together, the iconic presentation of the arrow-riddled body of the saint and the narrative scene of the Pavian intercession translated the written account of the Golden Legend into a riveting visual presentation.

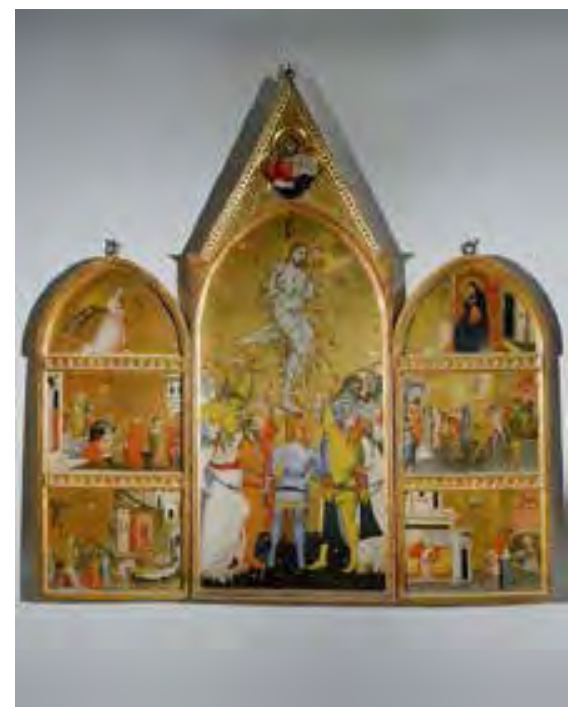

Fig. 8 Giovanni del Biondo, Martyrdom of Saint Sebastian with Scenes from His Life, late 14th century, tempera on panel, $224 \times 89 \mathrm{~cm}$. Florence, originally in the Duomo, currently in the Museo dell'0pera di S. Maria del Fiore, inv. 90 (artwork in the public domain)

As Saint Sebastian's healing actions during the plague at Pavia became better known through text and image, the excessive number of arrows that punctured the saint's body was soon connected to the piercing shafts that delivered the plague and destruction in pagan literature and Old Testament scripture. The tale of how Apollo inflicted plague on the Greeks during the Trojan War as told in Homer's Illiad was well known: "First he went for the mules and circling dogs but then, launching a piercing shaft at the men themselves, he cut them down in droves-and the corpsefires burned on, night and day, no end in sight." ${ }^{20}$ Familiar, too, was the Old Testament account of God as an agent of pestilence and plague in Deuteronomy 32:41-42, "I will render vengeance to mine enemies, and repay them that hate me. I will make my arrows drunk with blood." ${ }^{1}$

13 The arrows of Saint Sebastian's execution also led to his role in depictions of the Madonna della Misericordia. In his painting completed in 1372 during an outbreak of the plague in Genoa, Barnaba da Modena transformed the traditional image of the merciful Virgin Mary interceding for her petitioners into a powerful guardian who shields her worshipers from angels wielding plague-tipped arrows (fig. 9). ${ }^{22}$ By the middle of the fifteenth century, Saint Sebastian materializes under the mantle of the Madonna della Misericordia in three banners (gonfaloni) by Benedetto Bonfigli. Carried during penitential processions following recurrences of the plague, these banners show the body of Saint Sebastian pierced by a multitude of arrows which fail to threaten the citizens gathered around the Virgin Mary because he has absorbed their blows. In the gonfaloni, 
the mediating and protective role of the Virgin Mary is fortified by Saint Sebastian, who kneels at the outer edges of the Madonna's cloak and articulates the pleas of the people. This is made clear by the banderole that emerges from his mouth in the example from Corciano, "O Mary, flower of virgins, like a rose or a lily, pour out prayers to the Son for the salvation of the faithful" (fig. 10).

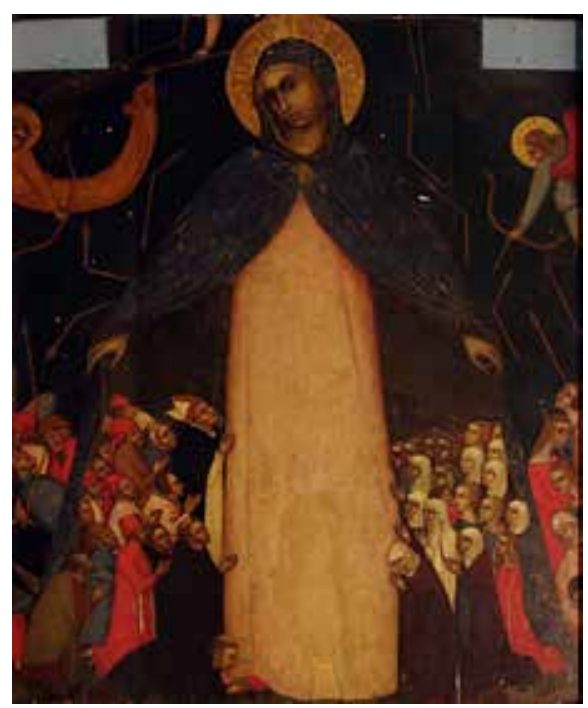

Fig. 9 Barnaba da Modena, Madonna della Misericordia, ca. 1372 , tempera on panel, $178 \times 186 \mathrm{~cm}$. Genoa, Santa Maria dei Servi (artwork in the public domain)

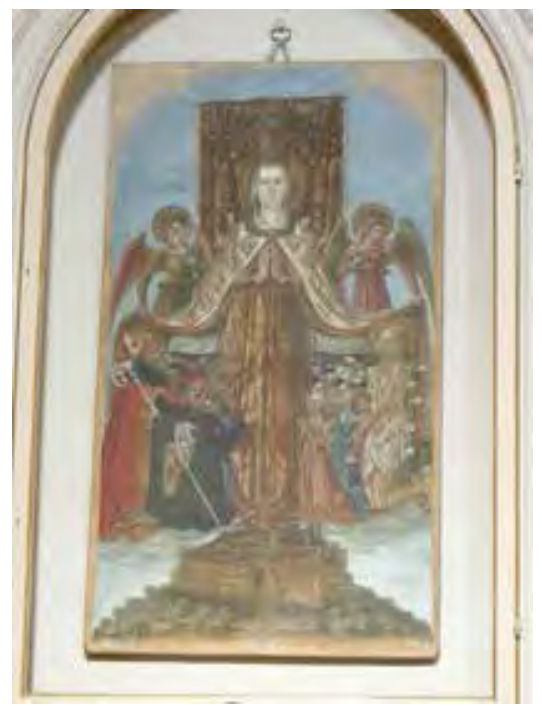

Fig. 10 Benedetto Bonfigli, Madonna della Misericordia, ca. 1472, tempera on canvas, 240 x $132 \mathrm{~cm}$. Corciano, Italy, Santa Maria Assunta (artwork in the public domain)

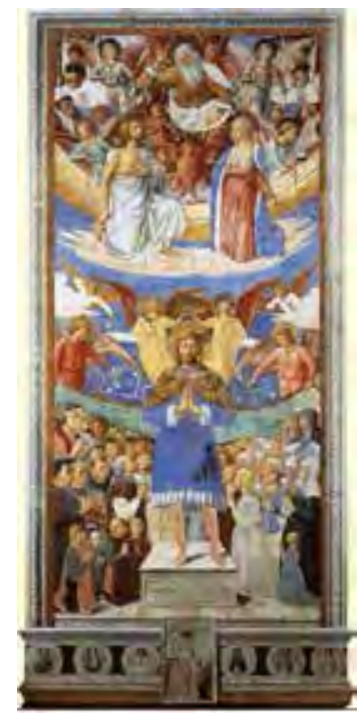

Fig. 11 Benozzo Gozzoli, Saint Sebastian, 1464, fresco, $523 \times 248 \mathrm{~cm}$. San Gimignano, Italy, Sant'Agostino (artwork in the public domain)

Saint Sebastian assumes the main intercessory role in a fresco by Benozzo Gozzoli in San Agostino in San Gimignano, which was completed only weeks after signs of the plague returned to the city in June 1464 (fig. 11). In this entirely novel iconographic solution, Saint Sebastian takes the place of the Madonna della Misericordia, who joins her son, Christ, in heaven. ${ }^{23}$ As in earlier depictions of the Virgin of Mercy, Saint Sebastian assumes both a mediating role, as the inscription on the plinth, "Sancte Sebastiane Intercede/pro devote populo tuo (Saint Sebastian intercede for your devoted people)," makes clear, and a defensive function, as the twisted arrows vanquished by his blue cloak reveal. Together, Saint Sebastian with the earth-bound supplicants below and Christ and the Virgin Mary above, appeal to God the Father, who holds a plague arrow. The people of San Gimignano gather beneath the mantle now borne by Saint Sebastian, who no longer absorbs the arrows of his attempted martyrdom and the plague but repels them. The epidemic was said to have ceased through Saint Sebastian's intercession on July 28, 1464, the very day of the painting's dedication, when reportedly thirty-eight people were delivered from the disease. $^{24}$

Now Saint Sebastian not only assumes the intercessory role of the Virgin Mary but with his long hair and beard, halo, and crown, he also resembles Christ. This is evident in a second work by Benozzo commissioned by the Collegiata "for the health of the people of San Gimignano and to procure their deliverance from death" (fig. 12). In this painting, the bound, Christ-like nude figure of Saint Sebastian is juxtaposed with Christ's bleeding hand, shown above his head, and with the depiction of the Crucifixion below his feet. The full visual presentation underscores the saint as an 
imitator of Christ who suffers for humanity by bearing the divine wrath of the plague. Both paintings by Benozzo in San Gimignano worked in concert to advance the cult of Saint Sebastian. ${ }^{25}$

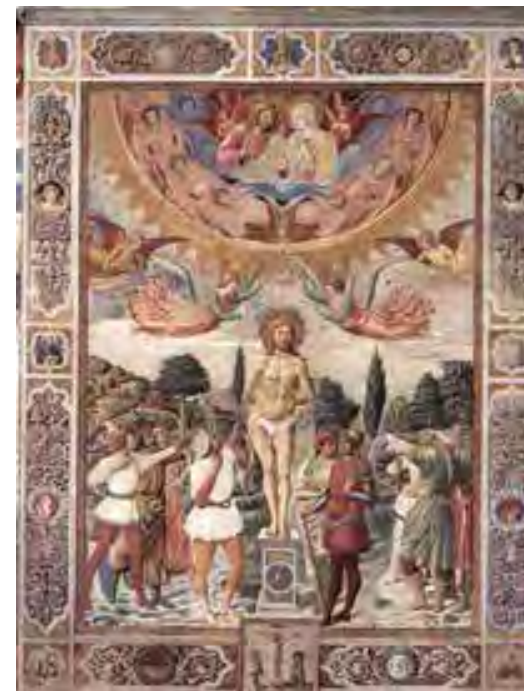

Fig. 12 Benozzo Gozzoli, Martyrdom of Saint Sebastian, 1465 , fresco, $525 \times 378 \mathrm{~cm}$. San Gimignano, Italy, Collegiate Church of Santa Maria Assunta (artwork in the public domain)

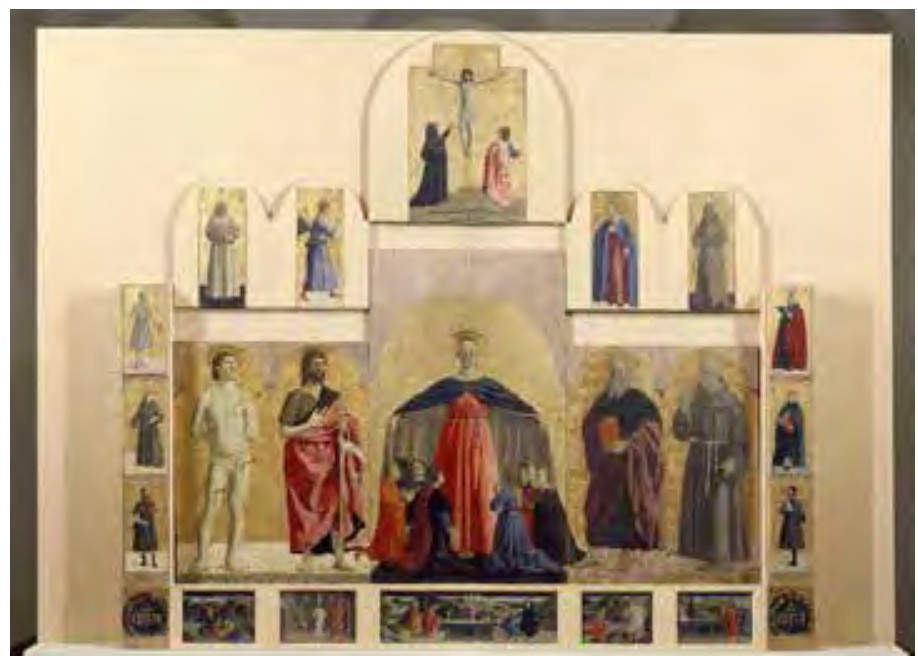

Fig. 13 Piero della Francesca, Polyptych of the Misericordia, ca. 1460-62, oil and tempera on panel, $273 \times 330 \mathrm{~cm}$. Sansepolcro, Italy, Pinacoteca Comunale (artwork in the public domain)

16 As waves of plague, typhus, and dysentery overwhelmed the cities of Italy in the later fifteenth century, the image of Saint Sebastian as a lone intercessor proliferated. In many of these, Saint Sebastian shed his overt associations with the Madonna della Misericordia and his pictorial and iconographic connections to Christ were strengthened. For example, in Piero della Francesca's Madonna della Misericordia, painted for a confraternity of mercy in Borgo Santo Sepolcro, the formidable saint stands alone, nearly nude, his body pierced by a small number of arrows-an allusion both to his martyrdom and to his efficacy in deflecting the scourge of the plague (fig. 13). ${ }^{26}$ Subsequently, Saint Sebastian either appears in narrative scenes of the attempted execution that resemble Christ's crucifixion or in devotional works that focus on the idealized exposed body of Saint Sebastian bound to an upright tree or column in imagery that is strikingly analogous to scenes of the Flagellation of Christ. The painting by Antonio and Piero Pollaiuolo completed in 1475 for the Servite church of Santissima Annunziata in Florence presents a richly detailed account of the attempted execution, while artworks by Antonello da Messina (1475-76), Sandro Botticelli (1474), and Perugino (ca. 1495) offer the alternative depiction of the isolated, suffering saint (fig. 14, fig. 15, fig. 16, and fig. 17).

17 As Louise Marshall has demonstrated, the lone figure of Saint Sebastian as a Christ-like redeemer eventually outnumbered narrative scenes. Representations that highlight the injured body of Saint Sebastian provided worshippers with a direct connection to his suffering and recovery and to his related intercessory role in relationship to the plague. ${ }^{27}$ Like Christ, Saint Sebastian experienced martyrdom, but did not die. He attracted the burst of plague arrows sent by God and grounded them harmlessly in his own flesh. To those praying for his intercession, Saint Sebastian's wounds corresponded to plague buboes and his miraculous recuperation mirrored Christ's resurrection 


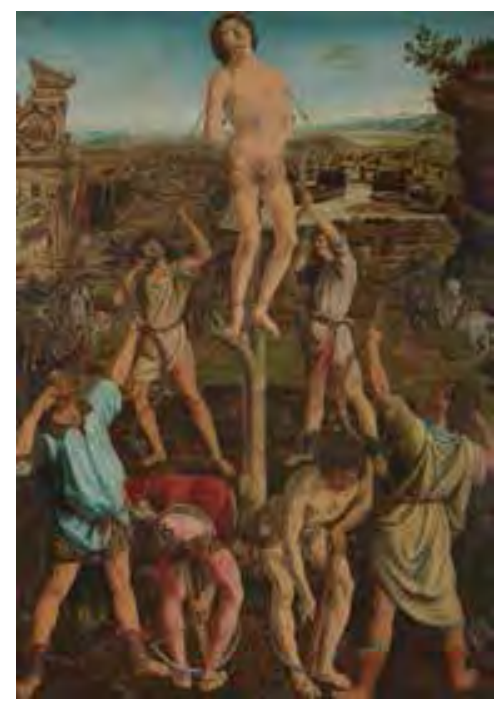

Fig. 14 Antonio and Piero del Pollaiuolo, The Martyrdom of Saint Sebastian, 1475 , oil on wood, $291.5 x$ $202.6 \mathrm{~cm}$. London, National Gallery, inv. NG292 (artwork in the public domain)

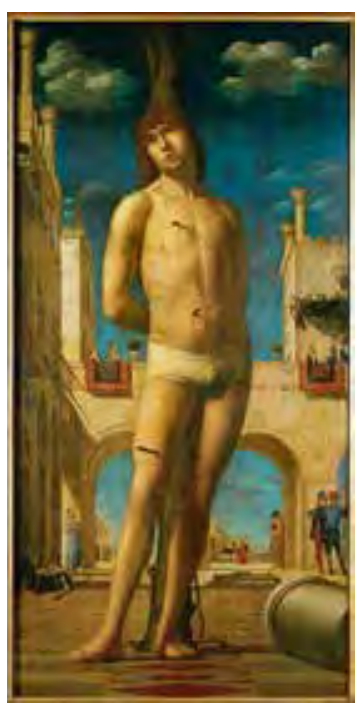

Fig. 15 Antonello da Messina, Saint Sebastian. 1475-76, oil on panel transferred to canvas, 171 x $85 \mathrm{~cm}$. Dresden, Gemäldegalerie Alte Meister,

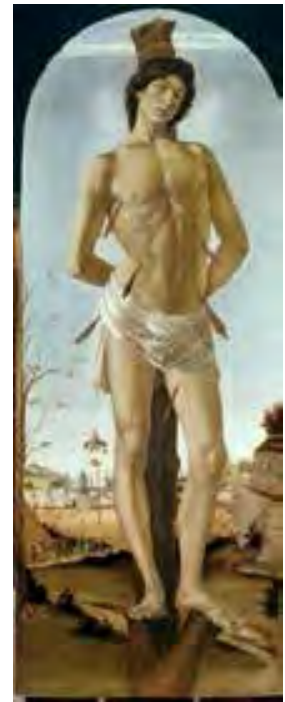

Fig. 16 Sandro Botticelli, Saint Sebastian, 1474 , oil on panel, $195 \times 75 \mathrm{~cm}$. Berlin, Staatliche Museen, Gemäldegalerie, inv. 1128 (artwork in the public domain)

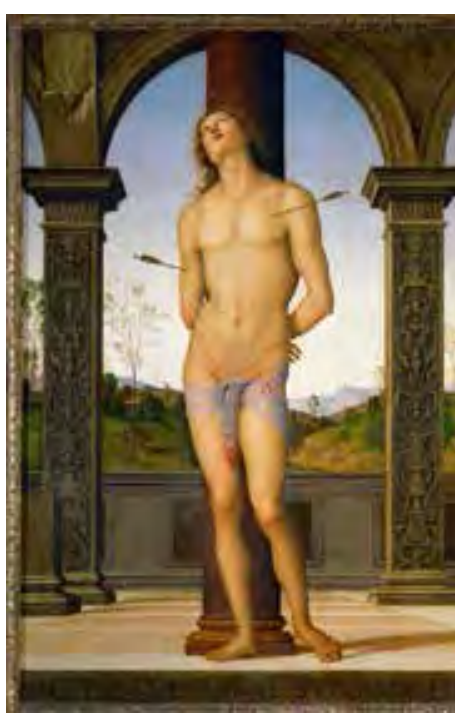

Fig. 17 Pietro Perugino, Saint Sebastian, ca. 1495, oil on panel, 170 x $116 \mathrm{~cm}$. Paris, Musée du Louvre, inv. 957 (artwork in the public domain)

that brought redemption and healing to humanity. ${ }^{28}$

18 The body of Saint Sebastian also served as a suitable subject for Italian artists wishing to demonstrate their skills in rendering an athletic male nude with the physical potency to withstand arrows. ${ }^{29}$ Sometimes, the accentuation of these features detracted from the saint's holiness. According to Giorgio Vasari, Fra Bartolomeo's painting from 1514-15 of the naked saint caused women to sin at the sight of it. ${ }^{30}$ The friar's shockingly realistic painting was quickly removed from the church of San Marco in Florence and is now known only by a copy in Fiesole ${ }^{31}$ (fig. 18).

19 This type of representation troubled the Roman Catholic reformers at the Council of Trent, held between 1545 and 1563. Contemporaneous with these discussions, the polemicist Giovan Andrea Gilio (d. 1584) pointed to the errors found in religious imagery and provided advice on how to produce decorous, didactic, and inspirational works of art. ${ }^{32}$ In his treatise from 1564, Gilio admonished artists who used the saints, including Saint Sebastian, as an excuse to depict 


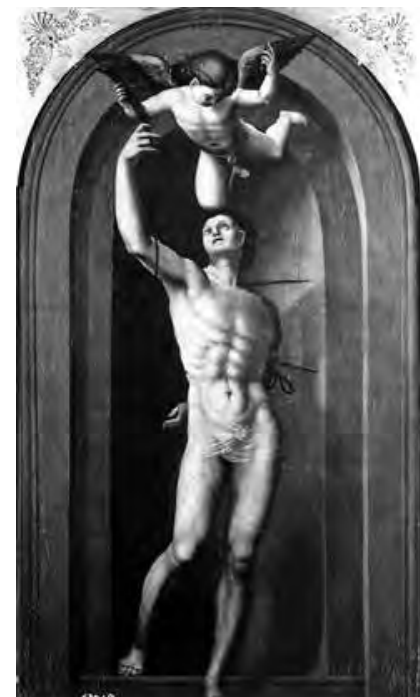

Fig. 18 Attributed to Ezechia da Vezzano, Saint Sebastian with an Angel, ca. 1526-27, oil on panel, $147 \times 86 \mathrm{~cm}$. Fiesole, Italy, San Francesco (artwork

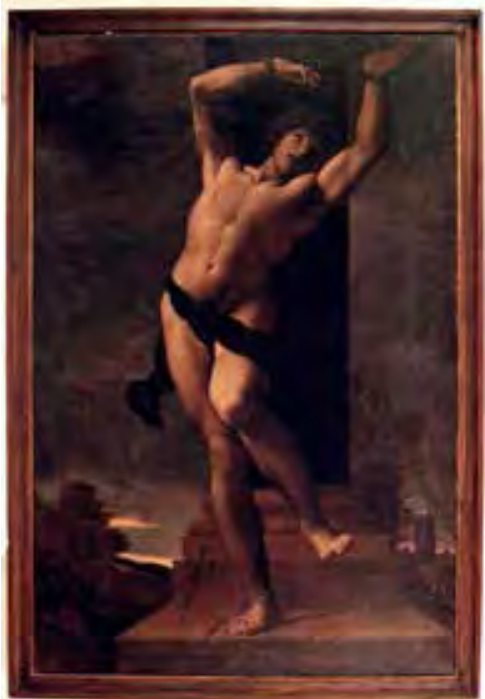

Fig. 19 Ludovico Carracci, Saint Sebastian, 1599, oil on canvas, $200 \mathrm{x}$ $130 \mathrm{~cm}$. Gravina in Puglia, Italy, Museo Fondazione Santomasi (artwork in the public domain)

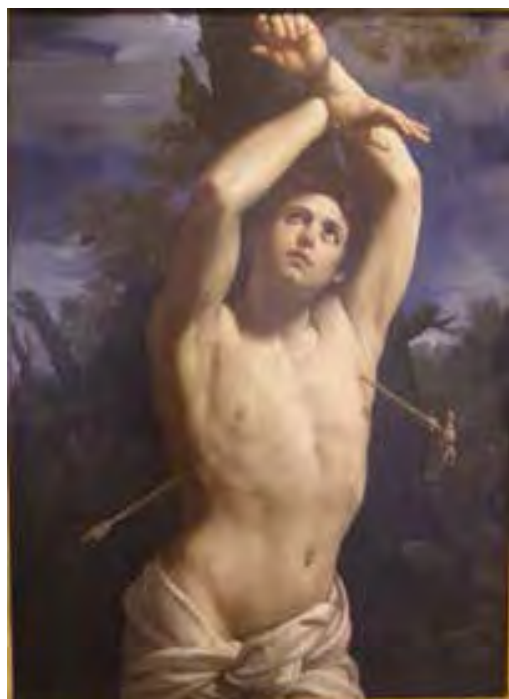

Fig. 20 Guido Reni, Saint Sebastian, ca. 1615, oil on canvas, 127 x $92 \mathrm{~cm}$. Genoa, Musei di Strada Nuova, Palazzo Rosso, inv. PR77 (artwork in the public domain)

perfected figures without emphasizing the reality of their martyrdoms..$^{3}$

Twenty years later, Gian Paolo Lomazzo (1538-1592) referred to Vasari's commentary on Fra Bartolomeo's lascivious Saint Sebastian in his guide to decorum in picture making. Although he had not seen the friar's painting, its reputation led him to recommend that artists should not paint the saint's body as sensually nude but, instead, as a martyr hanging from a tree with his flesh marked by bleeding wounds. ${ }^{34}$

21 Despite these specific renunciations, painters continued to emphasize the perfected figure of the saint, and even its frank sensuality and eroticism. Lodovico Caracci's painting from around 1600 and Guido Reni's seven depictions of the saint from the 1610s make this approach especially clear (fig. 19 and fig. 20). ${ }^{35}$ Reni's paintings were likely among the representations that troubled the post-Tridentine reformer and archbishop of Milan, Federico Borromeo, in 1624, when he lamented that so many painters showed off their skill by representing the saint as youthful, healthy, and nude even though historically the saint was "actually an old man."36

22 The practice of eroticizing Saint Sebastian reached as far as Utrecht, where Joachim Wtewael (1566-1638) completed his version in 1600 (fig. 21). In his representation, Wtewael focused on the sensual elegance of the smooth, twisting body of the saint in the center of the composition and referred to the impending execution by including a dramatically positioned cherub holding martyr's palms, two archers binding the saint to the tree trunk, and arrows, a cross bow, and a filled quiver. Only these peripheral features identify the central figure as Saint Sebastian, whose nearly nude body alone makes no direct connection to his role as a martyr or as an intercessory and redemptive healer. In her commentary on this painting, Anne E. Lowenthal noted the explicit sexuality of Wtewael's representation of Saint Sebastian and contrasted the piece to the "deeply felt religious expressions" found in the interpretations of van Honthorst and ter Brugghen. ${ }^{3}$ 


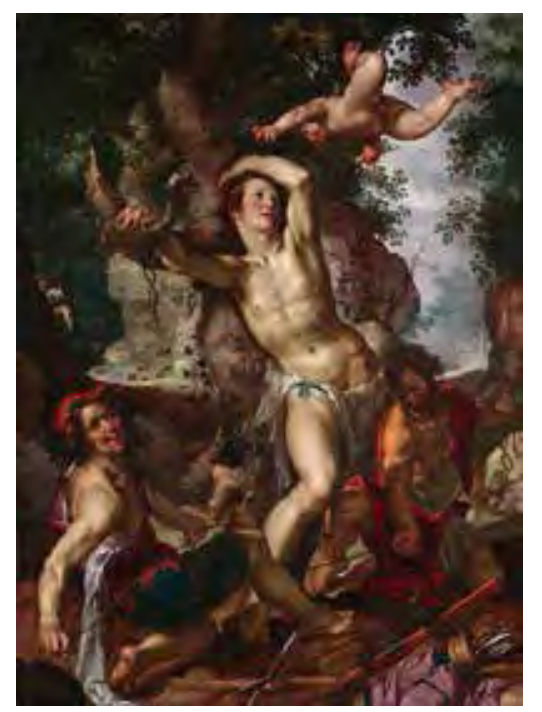

Fig. 21 Joachim Wtewael, Saint Sebastian, 1600 , oil on canvas, $169.5 \times 125 \mathrm{~cm}$. Kansas City, Nelson-Atkins Museum of Art, inv. F84-71 (artwork in the public domain)

23 Although ter Brugghen also idealized the body of Saint Sebastian in his painting from 1625, the saint no longer awaits or defeats death but instead barely clings to life. Here ter Brugghen recognized the rich pictorial and iconographic traditions established in Italy that linked the saint to Christ and the plague. At the same time and in contrast to the Italian versions, he introduced compositional and figural features that underscored the uncertainty of Saint Sebastian's recovery in a contemporary context, even as he highlighted the important role of Irene as the saint's healer.

\section{The Introduction of Irene, Saint Sebastian's Rescuer}

24 The addition of Irene was a fresh iconographic development, which emerged during the Counter Reformation with the scholarly writings of Cardinal Caesar Baronius (1538-1607). Having investigated a wide range of historical sources, Baronius modified the account of Saint Sebastian's martyrdom in both Martyrologium Romanum, published in 1586, and his authoritative twelve-volume church history, Annales Ecclesiastici. ${ }^{38}$ In the Martyrologium, Baronius recommended that Saint Sebastian be depicted as an old bearded man as he appeared in the mosaic in San Pietro in Vincoli. ${ }^{39}$ In volume three of the Annales (published in 1592) he recounted Irene's role in the rescue of Saint Sebastian. ${ }^{40}$ Although she had been mentioned by name in the fifth-century Passio and was referred to as "una casta donna" (a virtuous woman) in a seventh-century Milanese hymn, Irene did not appear in the popular Golden Legend, which simultaneously erased her role in Saint Sebastian's biography and kindled his associations with healing and the plague. ${ }^{41}$ In Baronius's amended description, Irene returns to the narrative as a female figure who comes at night to bury the executed victim but instead discovers he still lives. She rescues him and nurses him back to health in her home. The influence of Baronius's account is evident in the artworks that turn away from the solitary, sensualized figure of Saint Sebastian and instead underscore Irene's role as a healer.

25 Baronius's scholarship, especially the Annales, was enthusiastically embraced by a wide range of religious and secular leaders who advocated for vernacular versions that would reach an even greater number of readers. ${ }^{42}$ In the Netherlands, his work was quickly assimilated and translated by Roman Catholic scholars, who were moved by his well-argued claims supporting the history 
and legitimacy of the Roman Catholic faith. ${ }^{43}$

26 By the time ter Brugghen and his contemporaries turned to the story of Saint Sebastian, Baronius's account was widely known in translation. In his rendition from 1619 of the saint's biography, the Jesuit Heribert Rosweyde (1569-1629) described Irene's intention to bury Sebastian's body, but when she finds him alive she cures him.

The next night, the widow of Castulus, Irene of Rome, went secretly to the place where Saint Sebastian had been shot in order to retrieve his body to bury it, and found he was still alive. She brought him to her house and nursed him back to health. Christians heard of his recovery and came to admonish him and beg him with tears in their eyes that he should leave in order to avoid falling, again, into the hands of such a cruel tyrant. ${ }^{44}$

Additional passages tied to Saint Sebastian's feast day of January 20 recount his role as a plague saint.

This is the life and death of the glorious knight and most pious Captain of Christ, Sebastian, whom we may recognize as a double martyr because he was twice tormented and left for dead. All Christians have a great devotion to this saint because of the great power of his intercession, especially in the time of the plague, when he takes pity on all those who ask for his help. ${ }^{45}$

As these accounts of Saint Sebastian's final hours became broadly circulated, artists started to represent the figure of Irene as she attends the body of the seemingly dead Saint Sebastian at his execution or, in at least one unusual example, at his bedside.

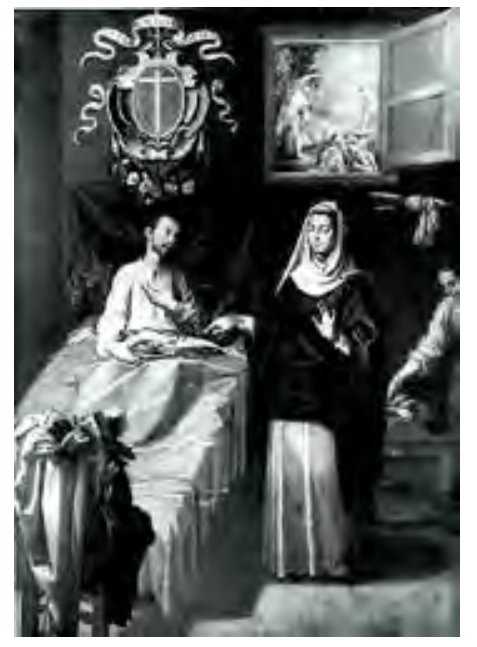

Fig. 22 Francisco Pacheco, Saint Sebastian

Tended by Irene, ca. $1616,292 \times 216 \mathrm{~cm}$.

Formerly Alcalá de Guadaíra, Spain, destroyed

1936 (artwork in the public domain)

At about the same time that Cornelis de Beer completed his painting (see fig. 2), the Spanish painter Francisco Pacheco (1564-1644) also depicted Irene in a painting intended for a hospital dedicated to Saint Sebastian, where a charitable confraternity cared for patients (fig. 22). ${ }^{46}$ Acknowledging the setting for this work, Pacheco showed Irene wearing the white-veiled habit of a convent nun who works in the infirmary, tending to a bearded mature Saint Sebastian, 
who convalesces on a bed in a domestic setting. ${ }^{47}$ Depicted as a sister, Pacheco's Irene grounds the remote story of Saint Sebastian in the present in a scene only rarely rendered and undoubtedly responsive to Baronius's restoration of Irene's central role. ${ }^{48}$

30 Visible through the back window of Pacheco's painting, a scene of the saint confronted by his executioners, based on a Flemish print by Jan Harmensz. Muller, presents the events that explain his wounded state. Irene's ministrations become the fulcrum for a look back to the recent past, recorded through the window, and to the imminent future, known to the viewer as the inevitable conclusion of Saint Sebastian's sacrifice. ${ }^{49}$ By emphasizing Irene's activities as a nurse, Pacheco focused on the moment in Saint Sebastian's narrative that directly paralleled the work of the contemporary confraternity members who volunteered to assist the impoverished sick. ${ }^{50}$ Since the arrows that caused the saint's wounds were metaphors for the arrival of the plague, the healing of Saint Sebastian aligned closely with this specific contagious disease. Against the backdrop of repeated outbreaks, depictions of Irene in Saint Sebastian's narrative underscored her willingness to risk her own life in the charitable act of burial, which was not necessary, and of healing, which was. Her actions had the effect of stimulating this inclination in others.

31 Thus the figure of Irene provided an alternative narrative for viewers of images that featured the martyrdom of Saint Sebastian. The traditional image of the solitary figure of the wounded saint with its striking pictorial and iconographic parallels to Christ that was so often represented in Italian art directly addressed the bodily needs of the afflicted as a miracle-working spiritual cure for a temporal ailment. The addition of Irene encouraged the community of the healthy to practice Christian charity by providing medical care to the sick, as straightforwardly depicted in $\mathrm{Pa}$ checo's work. In representations that unfold at the execution site, it also encouraged the provision of burial services for the dead, as implied in the paintings of ter Brugghen and his fellow Utrecht Caravaggists.

\section{Ter Brugghen's Painting and the Plague in Utrecht}

32 Ter Brugghen, van Baburen, and van Bijlert all avoided the fragmented distinction between the martyrdom of Saint Sebastian and Irene's caregiving found in Pacheco's representation of the newly acknowledged female protagonist. Instead, these artists expanded the traditional narrative to show Irene at the site of the attempted execution where she intends to retrieve the body of the presumably deceased martyr, but where she instead undertakes her initial acts of healing.

33 Distinguishing his work from that of his contemporaries, ter Brugghen underscored the precarious conditions of his own time as the backdrop for this scene from Saint Sebastian's life. Natasha Seaman has called this strategy "meta-historical": when ter Brugghen represented religious scenes, he incorporated iconographic, stylistic, and compositional archaisms along with characteristics drawn from Caravaggio's naturalism, materiality, and references to the present day. ${ }^{51}$ Following the conventional features of a traditional altarpiece in scale and size, the representation and placement of Saint Sebastian's body in the painting in Oberlin (see fig. 1) evokes comparisons with Christ as the Man of Sorrows and with the Crucifixion. The strikingly convincing three-dimensionality of the figures and the powerful tenebrism of the setting reveal the influence of Caravaggio's art. Yet the careful placement of the arrows, which clearly demar- 
cates the sign of a cross through the body of the suffering saint, draws attention to the physicality of the two-dimensional picture plane and highlights ter Brugghen's unique synthesis of illusion with the painted surface of his canvas.

34 As evidence of ter Brugghen's fusion of the past and present, Irene is shown carefully extracting one of the arrows. This unifies the sacrificial nature of the Christ-like saint with her practical charitable actions in a setting redolent with the reality of the plague in Utrecht. The ominous setting alludes to the ambient conditions of a plague summer. The body of the saint appears to suffer from the very disease he has been credited with curing, and Irene embodies the efforts of contemporary caregivers to provide burial services and medical treatment to the victims of the epidemic. The figure of Irene, in particular, speaks specifically to ongoing debates about how to respond to the plague. With her self-sacrificing willingness to remain and care for Saint Sebastian, Irene rejects fleeing, which was a common and rational reaction to the dreadful disease.

35 By the time he depicted the resolute Irene, ter Brugghen had witnessed the waxing and waning of the disease and confronted directly the threat of death by plague while living in Rome and Utrecht. These seasonal outbreaks typically occurred during warm weather, when ideal conditions existed for the flea whose bite transmitted the disease from rats to humans. ${ }^{52}$ For example, after a horrific summer of dysentery killed about one thousand people, the plague arrived in Utrecht in August 1624 when eighteen houses were identified and quarantined as "met de peste besmet" (plague contaminated). ${ }^{53}$ At that time, the regents decided to open up the pesthuis De Leeuwenbergh, where in September, the first deaths attributed to the plague were reported. ${ }^{54}$ By the time the year ended, about 500 people had died of the plague, around 20 percent of the total annual deaths $(2,721)$ in Utrecht, whose population numbered 30,000 to 35,000 inhabitants. ${ }^{55}$ With dismaying predictability, the plague recurred every season between 1625 and 1629. In November 1629, ter Brugghen likely died of the disease himself. ${ }^{56}$

36 The bubonic plague, which materialized with such alarming regularity, is caused by the bacillus Yersinia pestis, a bacterial disease found in rodents and transmitted to humans by fleas. The infected fleas thrive in relatively high temperatures and in the humid conditions typically found in rats' nests, woolen cloth, and grain stockpiles. The modern understanding of the plague, however, eluded the seventeenth-century medical and spiritual communities, who looked to other sources for the origins of the epidemic. In their comprehensive review of contemporary sources, Leo Noordegraaf and Gerrit Valk highlighted the common belief that the plague was caused by the sinful nature of humanity, which incited God's anger. This gave Gods (gift of God), which was a well-known synonym for the plague, was a divine punishment inflicted by natural causes, such as the bad air or miasma that emerged from the humid earth or the pestilentiaal zaat (pestilential seed) that came down from the heavens, bringing sickness and death directly into the vulnerable community. ${ }^{57}$

37 In the minds of ter Brugghen and his contemporaries, rotting refuse, stagnant water, and swampy earth gave birth to the rats, snakes, and other vermin that spread the epidemic. This decay was also linked to astronomical phenomena, such as odd conjunctions of planets, the appearance of comets and falling stars, and solar and lunar eclipses. The bile-colored sky in ter Brugghen's painting provides an appropriately diseased backdrop for an image that speaks to concerns raised by 
a plague epidemic. An ash-gray atmosphere predominates the right side of the composition and resembles the similarly tinted background in ter Brugghen's Crucifixion, which Helmut Nickel associated with an annular solar eclipse that occurred in the Netherlands on May 21, $1621 .{ }^{58}$ Ter Brugghen likely witnessed this event, when the dark disk of the moon obscured most of the sun but for a "ring of fire," which cast a seemingly supernatural light. The resulting strange coloring of the heavens resembles the eerie light of Saint Sebastian's execution in ter Brugghen's painting and points to the sky as a possible source of the disease (fig. 23).

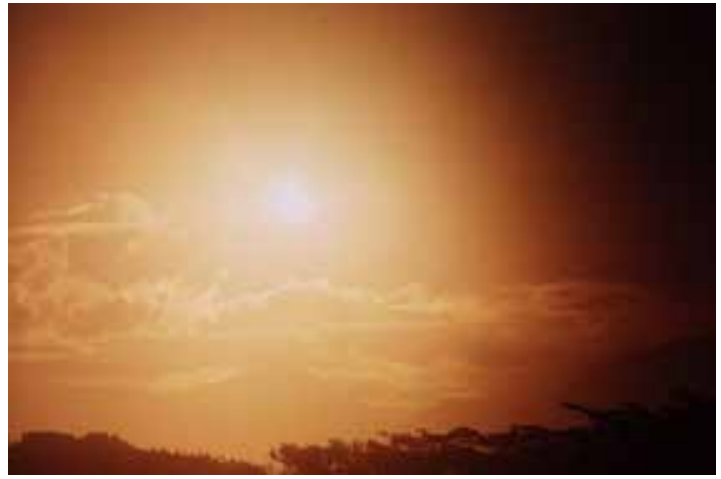

Fig. 23 Photo of annular solar eclipse taken in Madagascar in the mid-1970s (image in the public domain; photo: Creative Commons)

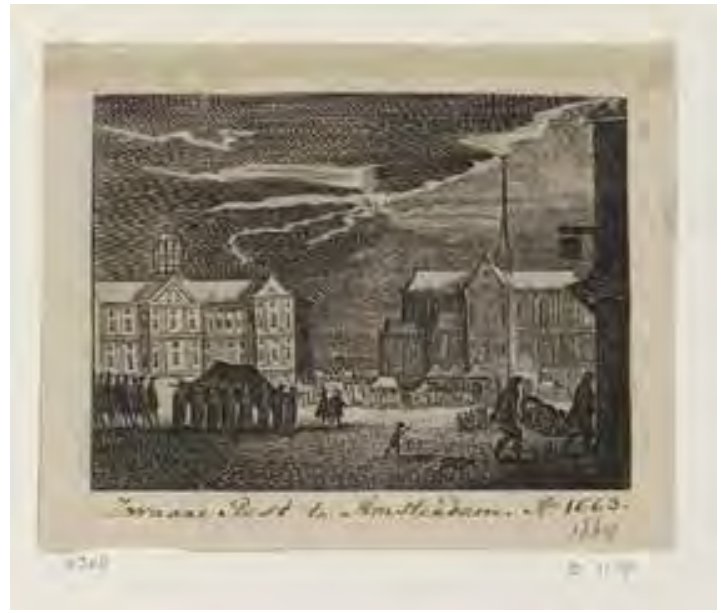

Fig. 24 "Van de Pestilentie," $9.5 \times 12 \mathrm{~cm}$, Afbeeldinge en Beschrijvinge van de drie aenmerckens-waerdige Wonderen in den jare 1664.'t Amsterdam en daer ontrent voorgevallen. Rotterdam, Atlas Van Stolk, \#11179 (photo: @ Atlas Van Stolk)

These associations were long-lived, as confirmed by a rare depiction of these phenomena dating to the severe plague years of 1663 and 1664. In a broadsheet on miraculous events, the sky comes alive with harbingers of disease in a scene entitled, "Van de Pestilentie" (fig. 24). ${ }^{59}$ In the print, a schielijck Vuur (shooting fire) and a gloejende Kogel (glowing bullet) light up the sky, portending the dark scene below, where citizens bury the plague dead and flee into the Nieuwe Kerk in Amsterdam. ${ }^{60}$

39 Another enduring sign of the plague found in the skies was the appearance of unfamiliar birds, a connection that had been noted as early as 1602 and as late as the harsh summer of 1664 . In ter Brugghen's painting, a small number of large birds glide ominously in the dusky atmosphere above the parched earth. When along with a fierce northerly wind, a flock of strange fowl appeared in the sky above Amsterdam in the late summer of 1624, the occurrence was linked to the plague, which was intensifying in all parts of the Netherlands. ${ }^{61}$ Together, the soaring black birds and the menacing sky of ter Brugghen's painting portend the devastation found on earth.

40 For ter Brugghen and his contemporaries, the decaying atmosphere fostered the plague and provided the environment for a series of additional earthly misfortunes. The bare landscape of ter Brugghen's setting includes a small number of frail trees isolated on the horizon line, which may stand as emblems of the ruinous state of the entire scene. In general, the barren backdrop would seem to evoke the economic hardships endured by the Dutch when war resumed with 
Spain in 1622. Higher taxation, trade embargoes, food shortages, and civic unrest led the Remonstrant preacher Paschier de Fijne (1588-1667) to ask in 1624, "If we cast our eyes over the whole land, do we not see that trade, industry, and the crafts decline everywhere, become lifeless and decay?" ${ }^{2}$ The anemic saplings also provide further evidence of God's wrath against human sinfulness. When trees were destroyed by a forceful icy wind that stripped leaves from branches and felled entire trunks in 1665, the same published account that reproduced the image of a fiery sky linked the storm to the plague and divine judgment. ${ }^{63}$

41 Peculiar celestial events, strange animal behavior, and overall decay were seen as omens of plague, and bad air was broadly understood as the natural origin of the disease. The means of contracting the disease once it was unleashed remained a mystery, however. Still, certain situations were to be avoided. Since the atmosphere itself was considered a primary source of the "pestilential seed," the sense of smell made one particularly vulnerable to the contagious agent. To counteract the decaying rubbish that fouled the air with the disease, citizens burned bonfires and made smoldering air fresheners of a variety of spices and herbs, including juniper berries, cloves, rosemary, lavender, sage, mint, and wormwood. ${ }^{64}$ Pomanders filled with nutmeg, cloves, and cinnamon were kept on the body and bundles of herbs and spices were placed at doors and windows. Even tobacco was thought to provide immunity. ${ }^{65}$ Smelling the sick or dead could also bring on the disease.

42 In order to avoid spreading the disease from an infected person, plague locations were quarantined and marked with a bunch of straw. ${ }^{6}$ Touching a plague victim or objects that had been in contact with the sick or with the miasma that caused the disease was also expected to lead to contamination. Items understood to be highly infectious included linens and wool, paper, and the fur or skins of animals, especially dogs, cats, rabbits, and pigs. The physician Ijsbrand Van Diemerbroek wisely counseled against touching "dirty and greasy" money that had been infected by the "bad air." ${ }^{67}$ According to some sources, even the senses of sight and hearing were susceptible because simply seeing cadavers and catching the sounds of the death carts could incite anxiety about the disease that would lead to infection. ${ }^{68}$

43 In ter Brugghen's painting, Irene and her attendant show total disregard of well-established warnings about the transmission of the plague. Both women directly smell, touch, and gaze intently at Saint Sebastian, whose very body reveals signs of the contagious disease. The position of the saint's extremities highlights the plague's most obvious symptoms of infection, the painful buboes, and the surface of the skin reveals the resulting trauma. With his right arm extended and his head falling to the side, Saint Sebastian presents his armpit and neck, both places where the inflamed lymph glands associated with the disease appear. Sheila Barker has identified the raised arm as a clear sign of the plague both in Poussin's The Plague of Ashdod from 1630-31 (fig. 25) and in Ludovico Ferrari's Saint Dominic Interceding before the Virgin for the Liberation from the Plague from 1635, painted for the city of Padua. ${ }^{69}$ In his description of the disease from 1624, the Amsterdam physician Jacobus Viverius (ca. 1571/72-1640) identified de Kol (the plague carbuncles or boils) and den Bubo (the buboes) as symptoms of the plague when they appear "aen den Hals, aen d'Oxels, aen de Liessen" (on the neck, in the armpits, and in the groin regions).${ }^{70}$ Swollen lumps of flesh along the contours of Saint Sebastian's body allude to these unambiguous indications of the plague. 


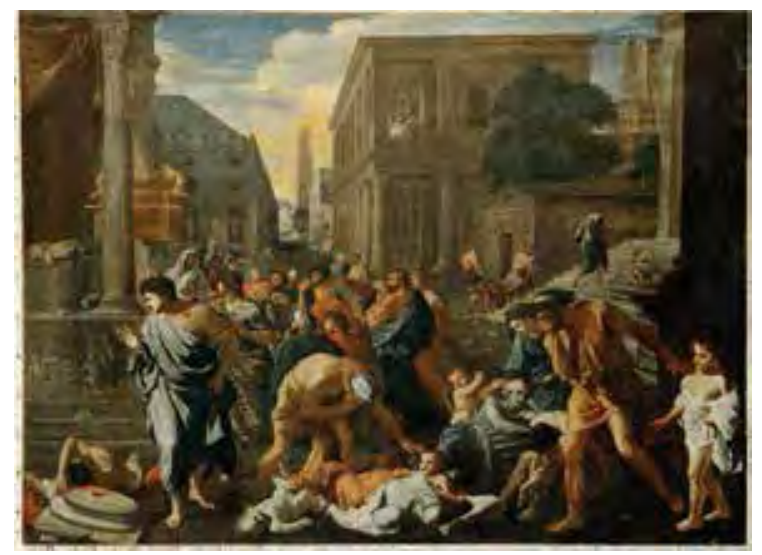

Fig. 25 Nicolas Poussin, The Plague at Ashdod, ca. 1630-31, oil on canvas, 148 x $198 \mathrm{~cm}$. Paris, Musée du Louvre, inv. 7276 (artwork in the public domain)

44 The darkening of the skin along Saint Sebastian's extremities also confirms the presence of the plague. The bruised colors of the flesh along the raised arm and neck, on the chest, and in the legs and feet refer not only to his near-death condition but also to the subcutaneous hemorrhaging brought on by infection when plague-ridden bodies "turned horribly black, swollen, and foul-smelling." ${ }^{71}$ This grayish discoloration of the skin, called a "telltale" symptom by Barker, is also evident in no less than four figures in Poussin's The Plague of Ashdod and in Pietro Bernardi's Saint Carlo Borromeo Praying among the Plague Victims from the 1610 s. $^{72}$ When this symptom, the peperkoornens (blackening) appeared, along with the pest-buylen (buboes) and the pest-koolen (carbuncles or boils), the Dutch physician Willem Swinnas conclusively diagnosed the plague as he argued in his 1664 publication Peststrijt. ${ }^{73}$ Actual modern-day occurrences of these signs of the plague resemble the rendering of specific passages of Saint Sebastian's body in ter Brugghen's painting (fig. 26, fig. 27, and fig. 28).

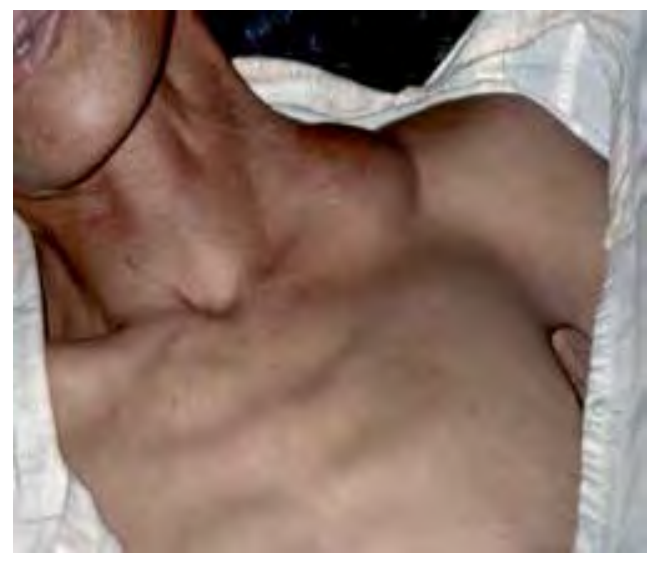

Fig. 26 Cervical bubo in a patient with bubonic plague in Madagascar (image in the public domain; photo: ( 2007 Elsevier Ltd.)

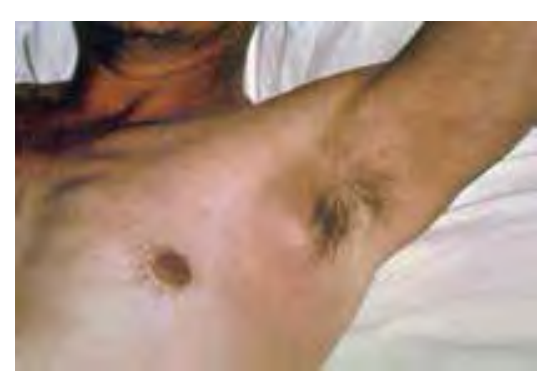

Fig. 27 Axillary bubo (image in the public domain; photo: Centers for Disease Control and Prevention)

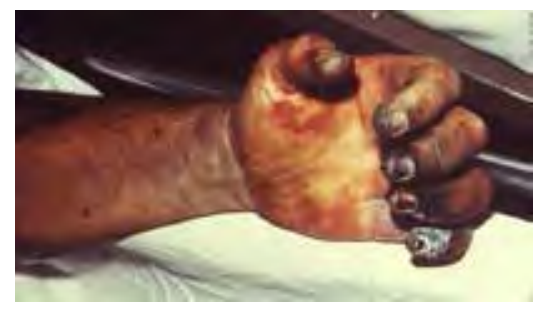

Fig. 28 Pest-kooren (hemorrhaging of the skin) (image in the public domain; photo: Centers for Disease Control and Prevention)

According to contemporary doctors, such as Viverius and Paul Barbette (died ca. 1666), the buboes and boils generally appeared after a fairly speedy progression of symptoms, which typically included headache, weakness in the limbs, fever and coughing, sometimes vomiting and diarrhea, and increasing fatigue. ${ }^{74}$ Medical treatments for these symptoms relied primarily on bloodletting and the administration of purgatives and medicines that brought about sweating to eliminate the 
plague poison from the body. ${ }^{75}$ As the disease progressed, the abscessed swellings under the skin were drawn out with strips of linen soaked in chamomile and angelica, a plague spice believed to be miraculous in its effects. These buboes and carbuncles were then lanced and covered with a plaster of red wine, yeast, figs, salt, and saffron. ${ }^{76}$ Temporal medicines gave way to spiritual remedies as death approached.

Attending to the needs of the body and the soul during outbreaks of the plague had often been the responsibility of the Cellebroeders and Cellezusters or Zwartezusters. These were Roman Catholic lay brothers and sisters, who first came to prominence during the Black Death. By the mid-fifteenth century, the Cellebroeders were well established in Leiden, Amsterdam, Dordrecht, and Utrecht, where they fed, washed, and nursed the victims of plague and other epidemics and buried those who did not survive. ${ }^{77}$ The Cellezusters, too, provided care to the sick and dying. Their community in Amsterdam, in particular, had close connections with Utrecht, where, in 1475, Bishop David of Burgundy had approved the establishment of their order. ${ }^{78}$

With the gradual secularization of church property in the 1580s and 1590s, the Cellebroeders lost their homes in Utrecht and were eventually relocated to properties near De Leeuwenbergh, where they continued to perform their traditional roles. ${ }^{79}$ While their identity as Roman Catholic healers faded, the lay brothers and their secular successors continued to be known as Cellebroeders, and they worked closely with two chief providers paid for by the city during the plague outbreaks of 1624 and $1625 .^{80}$ In Utrecht, an Amersfoort surgeon named Ernst vande Wal served as pestmeester (plague doctor), which required him to identify victims, to recommend quarantine at home or confinement in the plague house, and to confirm plague deaths. ${ }^{81}$ In addition, the city paid the salary of a pestziekenbezoeker (visitor of plague victims), who was appointed by the Dutch Reformed consistory and provided pastoral care to the sick and made reports on the health status of patients to the ministers, elders, and deacons. ${ }^{82}$ In August 1625, Utrecht appointed Abraham Cornelisz. to this post, which he held until May 1632. ${ }^{83}$ Importantly, the Cellebroeders served two functions not generally covered by the plague doctor or the plague visitor; they looked after the sick sent to De Leeuwenbergh, which by October 1624 was the only facility authorized by the city to receive plague victims, and they buried the dead.$^{84}$ In the civic ordinances of Utrecht in September 1624 and 1625, the Cellebroeders were named as the only parties allowed to enter plague houses and to remove bodies for transportation to demarcated burial grounds. ${ }^{85}$ In this regard, one article of their clothing is important to note. As they carried stretchers with the dead through the streets, the Cellebroeders were required to wear dark green cloaks and "banden van wit ende root" (ties of white and red) on their heads for easy identification. ${ }^{86}$

Ter Brugghen alluded to this very type of headdress by clothing Irene in a similarly rose-tinted white turban. Irene and her helper can thus be seen as undertaking tasks that the Cellebroeders, in particular, assumed during the plague, that is, treating the indigent infirm and burying the dead. Refusing to desert those in need, the women tending to Saint Sebastian, like the caregivers in Utrecht, risked their own lives to serve others.

This resolve to provide aid contradicted a common recommendation made by physicians during plague outbreaks. "Cito, longè, tarde" - flee immediately, stay far away, and be late in returning. ${ }^{87}$ Avoiding the plague and its victims presented the faithful with a dilemma: abandoning the 
sick might preserve their health but would also contravene Christian charity.

50 Although medical authorities recommended flight, religious denominations uniformly encouraged believers to remain with the sick and provide care and comfort. ${ }^{88}$ How stringently this expectation was endorsed depended on the faith. Most Roman Catholic sources maintained that avoiding infected localities and people was entirely appropriate when done in conjunction with the spiritual remedies of masses, confession, processions, and charitable works. Moreover, according to at least two Franciscan sources, physical flight might prompt the faithful to flee from sin and repent, which would placate God's anger and end the plague. ${ }^{89}$ Nevertheless, the most famous acts of Roman Catholic repentance recounted and depicted during ter Brugghen's lifetime were the penitential processions led by Carlo Borromeo (1538-1484), who resolutely remained in Milan during the pestilence of 1576-77. Indeed, close physical contact with the plague-stricken became the central narrative of Borromeo's iconography as a plague saint, whose canonization in Saint Peter's occurred in November 1610, when ter Brugghen was still living in the city. ${ }^{90}$ Direct ministry to ailing parishioners was also expected of both secular and regular priests in the Dutch Mission area. ${ }^{91}$ According to a report from 1656, forty priests, who were compared to martyrs, had died from the plague while serving Dutch parishioners. ${ }^{92}$

51 The nuanced attitude regarding flight found in Roman Catholic sources was also expressed by those Protestant faiths with a broad-minded view of predestination. These seventeenth-century Protestant theologians, pastors, and religious poets cited Old Testament narratives about fleeing from persecution, starvation, and war as support for escaping from the plague. ${ }^{93}$ On the other hand, orthodox Calvinists inflexibly objected to flight as an arrogant and hopeless attempt to avoid God's will. ${ }^{94}$ Even when authors admitted that the very old, the very young, and foreigners could legitimately flee, they adamantly insisted that most of the faithful should not run away but, instead, remain with the sick and dying. ${ }^{95}$

52 The uncompromising opposition to flight by orthodox Calvinists appeared in some surprising sources. In his introduction to a medical treatise by the renowned surgeon David van Mauden (1602), the staunch Calvinist Viverius addressed "de onchristelijke pestvlieders (the unchristian plague-fleers)" with the warning, "Flee anywhere you like. God will find you, unless you are fleeing from your sins. ${ }^{96}$ Later, in 1615, Viverius observed gratifyingly that the Amsterdammers who had fled the plague had died, while those who remained in the midst of the epidemic had been saved because "whoever abides in his office, God will abide with him."

53 The debate over flight even appeared on stage in Gerbrand Adriaensz Bredero's Spaansche Brabander. According to Paul Dijstelberge, the character Floris, a church beadle and part-time gravedigger, represents the strict Calvinist position against fleeing the plague. ${ }^{98}$ In Bredero's satirical tale, Floris buries the dead without fear because "de gave Gods" will either kill him or not and he has little control over the outcome.

54 Arguments against flight during periods of pestilence often referred to Psalm 91:2-3, which makes clear in the first two verses that God alone protects his people, "I will say of the Lord, He is my refuge and my fortress: my God; in him will I trust. Surely he shall deliver thee from the snare 
of the fowler, and from the noisome pestilence." 99

55 These words were the subject of Scherm en Schildt der kinderen Godes, published during the virulent plague season of 1623 by the orthodox Calvinist theologian Reverend Roelof Pietersz. (1584-1649). ${ }^{100}$ Based on his interpretation of the Old Testament text, Pietersz. argued against fleeing from the plague because it was beneficial to experience the misery and to engage in charitable acts, such as healing and burying. Pietersz. stated that the act of fleeing questions God's authority and implies that humanity can escape God's judgment. ${ }^{101}$

56 In his meditation, Pietersz. pointed to the purported author of the Psalm, King David, who did not flee but instead did penance for his sins. ${ }^{102}$ King David's resolve also figured in the 1656 publication, David's Credo, by the Amsterdam minister Casparus de Carpentier (1615-1667), which included an account of that year's plague in Amsterdam and a meditation on Psalm 16. In this Old Testament source, King David flees only to the protection of God as confirmed in verses 1 and 8, "Preserve me, O God: for in thee do I put my trust" and "I have set the Lord always before me: because he is at my right hand, I shall not be moved." ${ }^{103}$ Casparus argued God is a better tool for healing than running to a doctor or into the countryside. ${ }^{104}$ King David put his faith in God, and contemporary sufferers should, too.

57 King David represented a stalwart source for those who stayed behind to serve, such as the city appointed officials and the Cellebroeders who cared for plague sufferers during epidemics. In ter Bruggen's painting, too, Saint Sebastian and Irene did not flee, but remained to heal and convert. 24:10-14 and I Chronicles 21:8-13. When he offended God by ordering a census of his soldiers, King David was offered one of three punishments, and he chose the plague instead of famine or war. After three days of the pestilence killed 70,000 Israelites, King David begged for mercy, and God brought an end to the epidemic. ${ }^{105}$

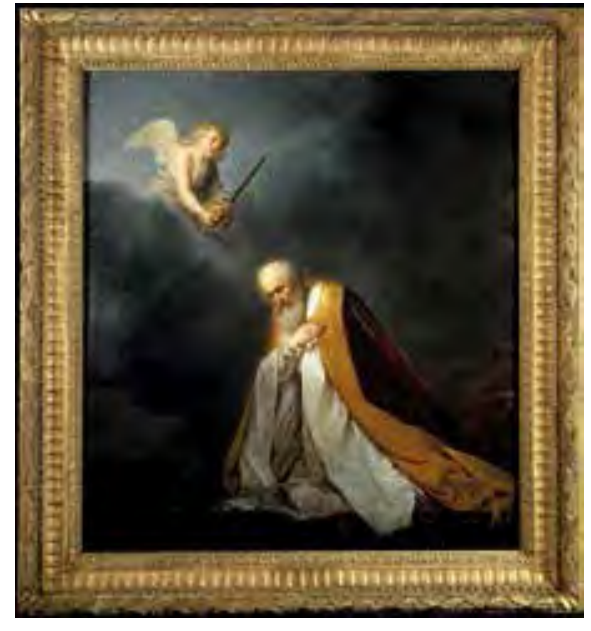

Fig. 29 Pieter de Grebber, King David Chooses from Three Plagues, ca. $1635-40$, oil on canvas, $94 \times 84.5 \mathrm{~cm}$. Utrecht, Het Catharijneconvent, inv. StCC s28 (artwork in the public domain)

59 Although infrequently depicted in art, King David's decision to inflict the plague on his people appeared in illustrated Bibles and in such rare works as the painting from 1635-40 by the Haarlem Roman Catholic painter Pieter de Grebber (fig. 29). ${ }^{106}$ To underscore King David's leadership 
when he suffered along with his people during the plague, ter Brugghen also included a pictorial reference to the Old Testament king. The brilliant red and gold fabric on which Saint Sebastian strangely sits refers to King David and to the community of Utrecht.

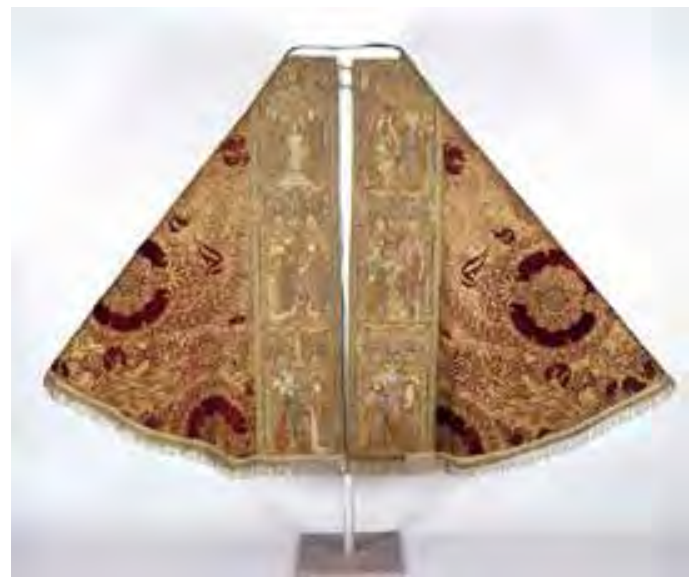

Fig. 30 Cope of David of Burgundy, ca. 1450-75, gold-brocaded red velvet, silk, and gold thread, $149 \times 314 \mathrm{~cm}$. Utrecht, Het Catharijneconvent, inv. ABM t2003 (artwork in the public domain)

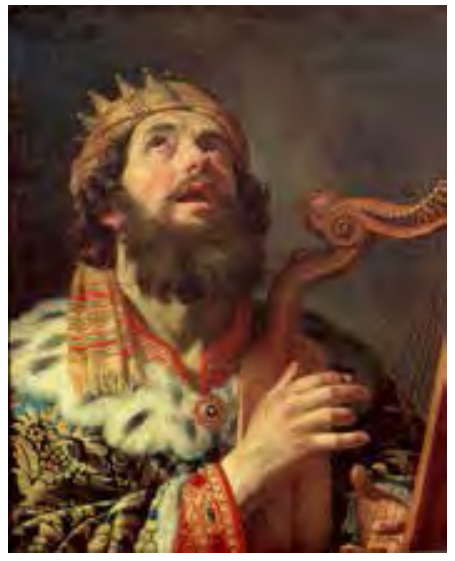

Fig. 32 Gerrit van Honthorst, David Playing the Harp, 1622, oil on canvas, $81 \times 65 \mathrm{~cm}$. Utrecht, Centraal Museum, inv. 8670 (artwork in the public domain)

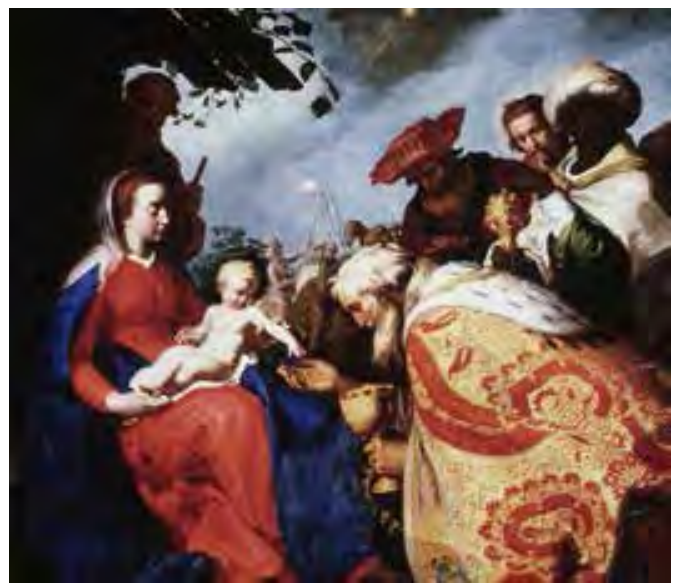

Fig. 31 Abraham Bloemaert, The Adoration of the Magi, 1624, oil on canvas, $193.7 \times 168.8 \mathrm{~cm}$. Utrecht, Centraal Museum, inv. 2575 (artwork in the public domain)

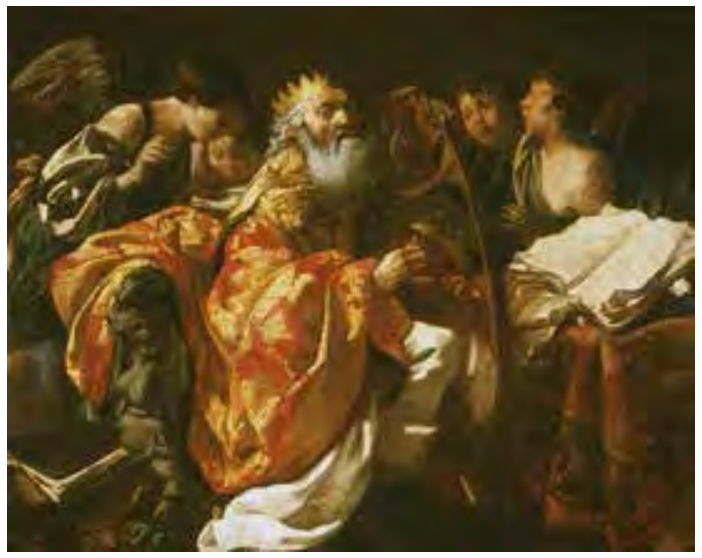

Fig. 33 Hendrick ter Brugghen, King David Playing His Harp Surrounded by Angels, ca. 1628, oil on canvas, 150 x $190 \mathrm{~cm}$. Warsaw, Muzeum Narodowe, inv. M.0b.529 (artwork in the public domain)

60 The rich brocade pattern of this cloth resembles the well-known similarly decorated ecclesiastical robe of David of Burgundy, bishop of Utrecht from 1456 to 1496, which was preserved in the Roman Catholic clandestine church of Saint Gertrude by 1626 (fig. 30). ${ }^{107}$ As early as 1620, the recognizable cope had served as the costume for Pilate in ter Brugghen's Crowning with Thorns. ${ }^{108}$ His likely teacher, the influential artist Abraham Bloemaert, had also adopted the liturgical garment for the figure of the magus Melchior in several versions of the Adoration of the Magi, including a work from 1624 (fig. 31). ${ }^{109}$ The general pattern of the cope of David of Burgundy also appeared in contemporary paintings of the Old Testament figure of King David by Honthorst in 1622 and by ter Brugghen in 1628 (fig. 32 and fig. 33). ${ }^{110}$ 
61 Although ter Brugghen did not explicitly reproduce the design of the famous cope in his painting of Saint Sebastian, the pomegranate pattern of his version closely resembles the carefully preserved item. Its use here, then, directly acknowledges the locally revered liturgical vestment of David of Burgundy and suggests an allusion to the similarly named King David and his refusal to abandon his people to the consequences of the plague. ${ }^{111}$ Furthermore, the pomegranate in the pattern was a well-known symbol of immortality that appropriately speaks to the saint's martyrdom and eternal life. ${ }^{112}$ The standard liturgical use of the cope also supports its association with Saint Sebastian in that it was worn during Sunday High Mass and in feast-day processions, when its red color symbolically recognized the sacrifice of martyrs. Not least, the cope was often used for such outdoor ceremonies as burials, the very act Irene and her helper have come to accomplish in ter Brugghen's painting. ${ }^{113}$

62 As an ecclesiastical vestment with specific connections to the rich history of Utrecht Roman Catholicism in general and to the elevated role of David of Burgundy in particular, the famous fabric in ter Brugghen's painting suggests a commission originating with a Roman Catholic clandestine church. ${ }^{114}$ As Xander van Eck has demonstrated, however, no historical documentation connects ter Brugghen's paintings to the Roman Catholics in Utrecht. ${ }^{115}$ Yet, ter Brugghen depicted not only a traditional Roman Catholic saint but added the post-Tridentine figure of Irene in a setting redolent with references to plague conditions experienced by the citizens of Utrecht in the 1620s. As a healer who did not flee, Irene serves to inspire contemporary caregivers. This significant content suggests a commission from an individual or institution providing care to plague sufferers without restricting the painting's message to any one religious denomination. ${ }^{116}$

63 Ter Brugghen's own religious orientation is unknown. Although Benjamin J. Kaplan has noted that the artist was married in the Dutch Reformed Church, and his children were baptized by Contra-Remonstrant ministers, he was not documented as a member of any specific denomination. ${ }^{117}$ Instead, ter Brugghen's personal religious conviction was possibly unaligned, as was the case for nearly one fourth of the population in Utrecht who had moved away from Roman Catholicism but hesitated to fully accept orthodox Calvinism. ${ }^{118}$ These so-called Libertines retained some traditional devotional practices from the past and also recognized individual agency, such as Irene's actions in the life of Saint Sebastian or the response of the Cellebroeders and other resolute caregivers, as a means of connecting with God, as declared by the newly established reformed faiths.

64 In multiconfessional Utrecht, Libertines lived and worshipped alongside Mennonites, Lutherans, Roman Catholics, and a diverse group of Dutch Reformed Protestants. Ter Brugghen's painting of Saint Sebastian Tended by Irene would seem to have provided comfort to all of them. ${ }^{119}$ However, its subject, incorporating as it does the iconographic tradition of Saint Sebastian's intercessory role during time of plague, clearly ties the artist's depiction to the faith of Rome, a religious conviction still shared by about 40 percent of the Utrecht population. ${ }^{120}$ More specifically, the introduction of Irene recognized the reforming spirit that broadened the appeal of Saint Sebastian to an audience of faithful caregivers who did not flee but remained to serve.

In his painting of Saint Sebastian and Irene, ter Brugghen achieved a balance of composition and content not evident in the works of his contemporaries. The diagonal alignment of the injured 
saint and the two women who have come to rescue him creates a powerful equilibrium. As they reach out to release the saint's hand and remove an arrow from his side their movements contrast potently with the immobility of Saint Sebastian's body and the stillness of the setting.

66 To sum up, ter Brugghen alludes to contemporary conditions experienced during plague outbreaks in order to communicate directly to his community during a time of hardship. The artist successfully unites the static figure of Saint Sebastian-embodying the Roman Catholic belief in his intercessory powers-with the actions of Irene and her assistant-who speak to the Protestant emphasis on the responsibilities of the individual. In this complex pictorial presentation, ter Brugghen brought together traditions that continued to nurture the spiritual needs of plague victims, while addressing the contemporary conditions of the plague and the faith-inspired response of caregivers.

\section{Acknowledgements}

My thanks to Susan Baker of the University of Houston-Downtown and to Natasha Seaman of Rhode Island College for reading numerous drafts of this article prior to submission. I also express my gratitude to the two JHNA anonymous readers for their careful reading and recommendations to address issues that I had avoided. My research on pictorial references to the plague in the Netherlands during the seventeenth century was specifically tied to ter Brugghen's painting in a paper presented at the Midwest Art History Society Session at the College Art Association Conference in 2013.

Valerie Hedquist is professor of art history and art criticism at the University of Montana in Missoula. She has published on Vermeer's religious art, Rembrandt's relationship with the Franciscans of Amsterdam, and on the genre imagery of Gabriel Metsu and its relationship to the plague. Her latest project is a book-length study on the reception of Thomas Gainsborough's Blue Boy from its beginnings in Bath, England, in the late eighteenth century to its cultural significance for a gay audience in the late twentieth century.

Valerie.Hedquist@mso.umt.edu

\section{List of Illustrations}

Fig. 1 Hendrick ter Brugghen, Saint Sebastian Tended by Irene, 1625, oil on canvas, 149 x 119.4 cm. Oberlin, Ohio, Oberlin College, Allen Memorial Art Museum, R. T. Miller, Jr. Fund, 1953, inv. AMAM 1953.256 (artwork in the public domain)

Fig. 2 Cornelis de Beer, Saint Sebastian Tended by Irene, 1610s, oil on canvas, 107 x $147 \mathrm{~cm}$. Sold at Christie's London, Dec. 13, 1996, lot no. 257 (artwork in the public domain)

Fig. 3 Gerrit van Honthorst, Saint Sebastian, ca. 1623, oil on canvas, 101 x 117 cm. London, National Gallery, inv. NG4503 (artwork in the public domain; photo credit: (c) The National Gallery, London) 
Fig. 4 Dirck van Baburen, Saint Sebastian Tended by Irene, ca. 1623-24, oil on canvas, $108.8 \mathrm{x}$ $153.5 \mathrm{~cm}$. Hamburg, Kunsthalle, inv. 788 (artwork in the public domain)

Fig. 5 Jan van Bijlert, Saint Sebastian Tended by Irene, 1624, oil on canvas, 113 x $100 \mathrm{~cm}$. Rohrau, Austria, Schloss Rohrau, Graf Harrach'sche Familiensammlung (artwork in the public domain)

Fig. 6 Attributed to Angelo Caroselli, Saint Sebastian and Irene, first half of 17th century, oil on canvas, 119 x $107 \mathrm{~cm}$. Moscow, State Pushkin Museum of Fine Arts, inv. 2686 (artwork in the public domain)

Fig. 7 Saint Sebastian, ca. $7^{\text {th }}$ century, mosaic. Rome, San Pietro in Vincoli (artwork in the public domain)

Fig. 8 Giovanni del Biondo, Martyrdom of Saint Sebastian with Scenes from His Life, late $14^{\text {th }}$ century, tempera on panel, $224 \times 89 \mathrm{~cm}$. Florence, originally in the Duomo, currently in the Museo dell'Opera di S. Maria del Fiore, inv. 90 (artwork in the public domain)

Fig. 9 Barnaba da Modena, Madonna della Misericordia, ca. 1372, tempera on panel, 178 x 186 $\mathrm{cm}$. Genoa, Santa Maria dei Servi (artwork in the public domain)

Fig. 10 Benedetto Bonfigli, Madonna della Misericordia, ca. 1472, tempera on canvas, 240 x 132 $\mathrm{cm}$. Corciano, Italy, Santa Maria Assunta (artwork in the public domain)

Fig. 11 Benozzo Gozzoli, Saint Sebastian, 1464, fresco, 523 x 248 cm. San Gimignano, Italy, Sant'Agostino (artwork in the public domain)

Fig. 12 Benozzo Gozzoli, Martyrdom of Saint Sebastian, 1465, fresco, 525 x 378 cm. San Gimignano, Italy, Collegiate Church of Santa Maria Assunta (artwork in the public domain)

Fig. 13 Piero della Francesca, Polyptych of the Misericordia, ca. 1460-62, oil and tempera on panel, 273 x $330 \mathrm{~cm}$. Sansepolcro, Italy, Pinacoteca Comunale (artwork in the public domain)

Fig. 14 Antonio and Piero del Pollaiuolo, The Martyrdom of Saint Sebastian, 1475, oil on wood, 291.5 x $202.6 \mathrm{~cm}$. London, National Gallery, inv. NG292 (artwork in the public domain)

Fig. 15 Antonello da Messina, Saint Sebastian. 1475-76, oil on panel transferred to canvas, $171 \mathrm{x}$ $85 \mathrm{~cm}$. Dresden, Gemäldegalerie Alte Meister, inv. 52 (artwork in the public domain)

Fig. 16 Sandro Botticelli, Saint Sebastian, 1474, oil on panel, 195 x 75 cm. Berlin, Staatliche Museen, Gemäldegalerie, inv. 1128 (artwork in the public domain)

Fig. 17 Pietro Perugino, Saint Sebastian, ca. 1495, oil on panel, 170 x $116 \mathrm{~cm}$. Paris, Musée du Louvre, inv. 957 (artwork in the public domain)

Fig. 18 Attributed to Ezechia da Vezzano, Saint Sebastian with an Angel, ca. 1526-27, oil on panel, 
147 x $86 \mathrm{~cm}$. Fiesole, Italy, San Francesco (artwork in the public domain; photo: (C) Alinari Archives, Florence)

Fig. 19 Ludovico Carracci, Saint Sebastian, 1599, oil on canvas, 200 x $130 \mathrm{~cm}$. Gravina in Puglia, Italy, Museo Fondazione Santomasi (artwork in the public domain)

Fig. 20 Guido Reni, Saint Sebastian, ca. 1615, oil on canvas, 127 x 92 cm. Genoa, Musei di Strada Nuova, Palazzo Rosso, inv. PR77 (artwork in the public domain)

Fig. 21 Joachim Wtewael, Saint Sebastian, 1600, oil on canvas, 169.5 x 125 cm. Kansas City, Nelson-Atkins Museum of Art, inv. F84-71 (artwork in the public domain)

Fig. 22 Francisco Pacheco, Saint Sebastian Tended by Irene, ca. 1616, 292 x $216 \mathrm{~cm}$. Formerly Alcalá de Guadaíra, Spain, destroyed 1936 (artwork in the public domain)

Fig. 23 Photo of annular solar eclipse taken in Madagascar in the mid-1970s (image in the public domain; photo: Creative Commons)

Fig. 24 "Van de Pestilentie," 9.5 x $12 \mathrm{~cm}$, Afbeeldinge en Beschrijvinge van de drie aenmerckens-waerdige Wonderen in den jare 1664.'t Amsterdam en daer ontrent voorgevallen. Rotterdam, Atlas Van Stolk, \#11179 (photo: (C) Atlas Van Stolk)

Fig. 25 Nicolas Poussin, The Plague at Ashdod, ca. 1630-31, oil on canvas, 148 x $198 \mathrm{~cm}$. Paris, Musée du Louvre, inv. 7276 (artwork in the public domain)

Fig. 26 Cervical bubo in a patient with bubonic plague in Madagascar (image in the public domain; photo: (c) 2007 Elsevier Ltd.)

Fig. 27 Axillary bubo (image in the public domain; photo: Centers for Disease Control and Prevention)

Fig. 28 Pest-kooren (hemorrhaging of the skin) (image in the public domain; photo: Centers for Disease Control and Prevention)

Fig. 29 Pieter de Grebber, King David Chooses from Three Plagues, ca. 1635-40, oil on canvas, $94 \mathrm{x}$ $84.5 \mathrm{~cm}$. Utrecht, Het Catharijneconvent, inv. StCC s28 (artwork in the public domain)

Fig. 30 Cope of David of Burgundy, ca. 1450-75, gold-brocaded red velvet, silk, and gold thread, 149 x $314 \mathrm{~cm}$. Utrecht, Het Catharijneconvent, inv. ABM t2003 (artwork in the public domain)

Fig. 31 Abraham Bloemaert, The Adoration of the Magi, 1624, oil on canvas, $193.7 \times 168.8 \mathrm{~cm}$. Utrecht, Centraal Museum, inv. 2575 (artwork in the public domain)

Fig. 32 Gerrit van Honthorst, David Playing the Harp, 1622, oil on canvas, 81 x $65 \mathrm{~cm}$. Utrecht, Centraal Museum, inv. 8670 (artwork in the public domain) 
${ }^{1}$ Leonard J. Slatkes and Wayne Franits, The Paintings of Hendrick ter Brugghen 1588-1629, Catalogue Raisonné (Amsterdam: John Benjamins Publishing, 2007), 4-5; and Marten Jan Bok and Yoriko Kobayashi, "New Data on Hendrick ter Brugghen," Hoogsteder-Naumann Mercury 1 (1985): 7-34.

${ }^{2}$ Christiaan Schuckman, "Did Hendrick ter Brugghen Revisit Italy? Notes from an Unknown Manuscript by Cornelis de Bie," Hoogsteder-Naumann Mercury 4 (1986): 7.

${ }^{3}$ Slatkes and Franits, The Paintings of Hendrick ter Brugghen, 5; and Wayne Franits, The Paintings of Dirck van Baburen ca. 1592/93-1624, Catalogue Raisonné (Amsterdam: John Benjamins Publishing, 2013), 5, 35.

${ }^{4}$ J. Richard Judson and Rudolf E. O. Ekkart, Gerrit van Honthorst 1592-1656 (Ghent: Davaco Publishers, 1999), 5, 14.

${ }^{5}$ Paul Huys Janssen, Jan van Bijlert 1597/98-1671 Catalogue Raisonné (Amsterdam: John Benjamins Publishing, 1998), 38-40.

${ }^{6}$ Ronald Rommes, "Op het spoor van de dood, de pest in en rond Utrecht," Jaarboek Oud-Utrecht (1991): 99-101.

${ }^{7}$ Franits, The Paintings of Dirck van Baburen, 42.

${ }^{8}$ While still in Italy in 1615, van Baburan produced a full-length, vertical version of Saint Sebastian (now lost) for Santa Maria dei Servi in Parma. His horizontal representation of Saint Sebastian and Irene (Kunsthalle, Hamburg) was frequently reproduced. Judson and Ekkart, Gerrit van Honthorst, 103-5; and Franits, The Paintings of Dirck van Baburen, 41-42; for the Parma painting, 208-9, 238; for the Hamburg painting, 172-74.

${ }^{9}$ Janssen, Jan van Bijlert, 107, and 225.

${ }^{10}$ Slatkes and Franits, The Paintings of Hendrick ter Brugghen, 21.

${ }^{11}$ In 1954 Walter Stechow recognized similarities between this work and ter Brugghen's painting. Janssen, Jan van Bijlert, 107; and http://www.italian-art.ru/canvas/17-18 century/c/caroselli angelo/saint sebastian and saint irene/index.php?lang=en.

${ }^{12}$ Wayne Franits, "Dirck van Baburen and the "Self-Taught" Master, Angelo Caroselli" JHNA 5, no. 2 (Summer 2013); DOI:10.5092/jhna.2013.5.2.5 http://www.jhna.org/index.php/past-issues/ volume-5-issue-2-2013/195-wayne-franitsPublished

${ }^{13}$ Louise Marshall, "Manipulating the Sacred: Image and Plague in Renaissance Italy," Renaissance Quarterly 47, no. 3 (Autumn 1994): 488-89.

${ }^{14}$ Sheila Barker, “The Making of a Plague Saint: Saint Sebastian's Imagery and Cult before the Counter-Reformation," in Piety and Plague: From Byzantium to the Baroque, eds. Franco Mormando and Thomas Worcester (Kirksville, MO: Truman State University Press, 2007), 90-91. ${ }^{15}$ Paul the Deacon, History of the Lombards, trans. William Dudley Foulke, LLD, ed. Edward Peters (1907; repr., Philadelphia: University of Pennsylvania, 1974), Book 6, Chapter 5, 254-55; and Marshall, "Manipulating the Sacred," 489.

${ }^{16}$ Barker, "The Making of a Plague Saint," 97.

${ }^{17}$ Barker, "The Making of a Plague Saint," 97.

${ }^{18}$ The frescoes were destroyed in the seventeenth century, when Antonio Eclissi made drawings of the scenes. Laura Marchiori, "Medieval Wall Painting in the Church of Santa Maria in Pallara, Rome: The Use of Objective Dating Criteria," Papers of the British School at Rome 77 (2009): 226.

${ }^{19}$ Barker, “The Making of a Plague Saint," 101-4.

${ }^{20}$ Homer, The Illiad, trans. by Robert Fagles (New York: Penguin Books, 1998), Book 1, 79.

${ }^{21}$ Marshall, "Manipulating the Sacred," 493. 
${ }^{22}$ Louise Marshall, "Confraternity and Community: Mobilizing the Sacred in Times of Plagues," in Confraternities and the Visual Arts in Renaissance Italy: Ritual, Spectacle, Image, eds. Barbara Wisch and Diane Cole Ahl (Cambridge and New York: Cambridge University Press, 2000), 21-23. ${ }^{23}$ Avraham Ronen, “Gozzoli's St. Sebastian Altarpiece in San Gimignano," Mitteilungen des Kunsthistorischen Institutes in Florenz 32, no. 1/2 (1988): 88.

${ }^{24}$ Diane Cole Ahl, Benozzo Gozzoli (New Haven, Conn.: Yale University Press, 1996), 142-44, 278 (Document 12).

${ }^{25}$ Ahl, Benozzo Gozzoli, 145-46.

${ }^{26}$ Ronald Lightbown, Piero della Francesca (New York: Abbeville Press, 1992), 43.

${ }^{27}$ Marshall," Manipulating the Sacred," 500.

${ }^{28}$ Marshall, "Manipulating the Sacred," 495-96; and Allie Terry-Fritsch, "Proof in Pierced Flesh: Caravaggio's Doubting Thomas and the Beholder of Wounds in Early Modern Italy," in Beholding Violence in Medieval and Early Modern Europe, eds. Allie Terry-Fritsch and Erin Felicia Labbie (Burlington, Vt.: Ashgate, 2012), 24.

${ }^{29}$ Bette Talvacchia, "The Double Life of St. Sebastian in Renaissance Art," in The Body in Early Modern Italy, eds. Julia L. Hairston and Walter Stephens (Baltimore: The Johns Hopkins University Press, 2010), 228.

${ }^{30}$ Janet Cox-Rearick, "Fra Bartolomeo's St. Mark Evangelist and St. Sebastian with an Angel," Kunsthistorisches Institut in Florenz 18, no. 3 (1974): 338, 340.

${ }^{31}$ Cox-Rearick, "Fra Bartolomeo's St. Mark Evangelist," 332-34.

${ }^{32}$ Paul Smith and Carolyn Wilde, eds., A Companion to Art Theory (Oxford and Malden, Mass.: Blackwell Publishing, 2002), 51-52.

${ }^{33}$ Giovanni Andrea Gilio, Dialogo nel Quale si Ragiona degli Errori e degli Abusi de' Pittori circa l'Istorie (Camerino, 1564), 41, 42, 81, 113; and Paola Barocchi, Trattati d'arte del Cinquecento: Fra manierismo e Controriforma (Bari: Gius Laterza \& Figli, 1961), 2: 41, 42, 81, 113.

${ }^{34}$ G. P. Lomazzo, Trattato dell'Arte della Pittura (Milan, 1585), Book VI, Chapter 35, 366.

${ }^{35}$ Richard E. Spear, The "Divine" Guido: Religion, Sex, Money and Art in the World of Guido Reni (New Haven, Conn.: Yale University Press, 1997), 67-76; and Piero Boccardo and Xavier F. Salomon, eds., The Agony and the Ecstasy: Guido Reni's St. Sebastians, (Milan: Silvana Editoriale, 2007), 82-87.

${ }^{36}$ Federico Borromeo, Sacred Painting/Museum, ed. and trans. Kenneth S. Rothwell Jr. (Cambridge, Mass.: Harvard University Press, 2010), 29 (Book 1, Chapter 8, "Age").

${ }^{37}$ Anne W. Lowenthal, Joachim Wtewael and Dutch Mannerism (Doornspijk: Davaco, 1986), 93-94.

${ }^{38}$ Josephine von Henneberg, "Cardinal Caesar Baronius, The Arts, and the Early Christian Martyrs," in Saints and Sinners: Caravaggio and the Baroque Image, ed. Franco Mormando (Boston:

Boston College, McMullen Museum of Art/ Chicago: University of Chicago Press, 1999), 139; and Cyriac K. Pullapilly, Caesar Baronius, Counter-Reformation Historian (Notre Dame, Ind.: University of Notre Dame Press, 1975), 37-42, 49.

${ }^{39}$ von Henneberg, "Cardinal Caesar Baronius," 139, 145.

${ }^{40}$ Caesar Baronius, Annales Ecclesiastici, ed. A. Theiner (Brussels, 1864), 3:295-96 (Caii Annus, 3, anno 286).

${ }^{41}$ Francesco Danieli, La freccia e la palma (Rome: GAIA Edizioni Universitarie Romane, 2007), 38.

${ }^{42}$ Pullapilly, Caesar Baronius, 55. 
${ }^{43}$ Charles H. Parker, Faith on the Margins: Catholics and Catholicism in the Dutch Golden Age (Cambridge, Mass.: Harvard University press, 2008), 55. In Utrecht, the Jesuit Heribert Rosweyde issued a Latin version of the Martyrologium Romanum in 1613 and translated a popular compendium of Baronius's Annales (Generale Kerckelycke Historie) in 1623 to which he added his own history of the Roman Catholic faith in the Netherlands. A Dutch translation of Baronius's Martyrologium Romanum (Roomsch Martelaren-Boeck) had already been completed in 1600 by Henry Adriani, a chaplain of an Antwerp almshouse. Jan Machielsen, "Heretical Saints and Textual Discernment: The Polemical Origins of the Acta Sanctorum (1643-1940)" in Angels of Light? Sanctity and the Discernment of Spirits in the Early Modern Period, eds. Clare Copeland and Jan Machielsen (Leiden and Boston: Brill, 2013), 124; von Henneberg, "Cardinal Caesar Baronius," 145; F. A. M. van Eekelen, "Van Geluwe en zijn strijd om de martelaars," Tijdschrift voor Nederlandse Kerkgeschiedenis 14 (June 2011): 60-68; and A. J. van der Aa, Biographisch Woordenboek der Nederlanden (Haarlem: J. J. van Brederode, 1874), 16:492. Rosweyde's translation of another popular hagiographic source that incorporated Baronius's scholarship, the Generale Legende der Heyligen, was available in no less than four different editions before 1650. Rosweyde's Generale Legende der Heyligen was derived from a publication by the Spanish Jesuit Pedro de Ribadeneyra, entitled Fleur de Saints. Willem Pieter Cornelis Knuttel, Nederlandsche Bibliographie van Kerkgeschiedenis (Amsterdam: Frederik Muller, 1889), 279.

${ }^{44}$ Heribert Roswyde, Generale Legende der Heylighen met het leven Jesu Christi ende Marie: Vergadert wt de H. Schrifture (Antwerp, 1649), 1:204.

${ }^{45}$ Roswyde, Generale Legende der Heylighen, 1:204.

${ }^{46}$ John F. Moffitt, "Francisco Pacheco and Jerome Nadal: New Light on the Flemish Sources of the Spanish "Picture-within-the-Picture," Art Bulletin 72, no. 4 (December 1990): 632.

${ }^{47}$ Barbara Mujica, "Healing on the Margins: Ana de San Bartolomé, Convent Nurse," Early Modern Studies Journal 6 (2014): 129.

${ }^{48}$ Karim Ressouni-Demigneaux, “The 'Imaginary' Life of Saint Sebastian," in The Agony and the Ecstasy, ed. Boccardo and Salomon, 28.

${ }^{49}$ Moffitt, "Francisco Pacheco," 632.

${ }^{50}$ Sheila Barker, "Plague Art in Early Modern Rome: Divine Directives and Temporal Remedies," in Hope and Healing: Painting in Italy in a Time of Plague, 1500-1800 (Chicago: University of Chicago Press, 2005), 47-48.

${ }^{51}$ Natasha T. Seaman, The Religious Paintings of Hendrick ter Brugghen: Reinventing Christian Painting after the Reformation in Utrecht (Farnham, UK, and Burlington, Vt.: Ashgate, 2012), 73-83.

${ }^{52}$ Ronald Rommes, "Pest in perspectief: Aspecten van een gevreesde ziekte in de vroegmoderne tijd," Tijdschrift voor sociale geschiedenis 16 (1990): 250.

${ }^{53}$ Rommes, "Op het spoor van de dood," 100.

${ }^{54}$ Rommes, "Pest in perspectief," 264-65.

${ }^{55}$ Rommes, "Pest in perspectief," 254; and Rommes, "Op het spoor van de dood," 120.

${ }^{56}$ Albert Blankert, Leonard J. Slatkes et al., Nieuw licht op de Gouden Eeuw: Henrick ter Brugghen en tijdegenoten (Utrecht: Central Museum, and Braunschweig: Herzon Anton Ulrich-Museum, 1986-87), 67; and Rommes, "Op het spoor van de dood," 101.

${ }^{57}$ Leo Noordegraaf and Gerrit Valk, De gave Gods: De pest in Holland vanaf de late Middeleeuwen (Bergen: Octavo, 1988), 31-32; and Willem Frijhoff, "Gods gave afgewezen: Op zoek naar genezing van de pest: Nijmegen, 1635-1636," Volkskundig Bulletin 17, no. 2 (1991): 143-70. 
${ }^{58}$ Helmut Nickel, “The Sun, the Moon, and an Eclipse: Observations on "The Crucifixion with the Virgin and Saint John" by Hendrick Ter Brugghen," Metropolitan Museum Journal 42 (2007): $121-24$.

${ }^{59}$ This source was published by Marcus Doornick at the beginning of 1665 and included poems by the poet and polemicist Jan Zoet. Rudolf Cordes, Jan Zoet, Amsterdammer 1609-1674: Lleven en Werk van een Kleurrijk Schrijver (Hilversum: Verloren, 2008), 502-3.

${ }^{60}$ Atlas van Stolk, \#11179, Afbeelding en Beschrijvinge van de drie aenmerckens-waerdige Wonderen in den Jare 1664. 't Amsterdam en daer ontrent voorgevallen. Noordegraaf and Valk, De gave Gods, 107-8.

${ }^{61}$ Noordegraaf and Valk, De gave Gods, 109.

${ }^{62}$ Jonathan I. Israel, The Dutch Republic: Its Rise, Greatness, and Fall 1477-1806 (Oxford: Clarendon Press, 1995), 479.

${ }^{63}$ Atlas van Stolk, \#11179, Afbeelding en Beschrijvinge.

${ }^{64}$ Rommes, "Op het dpoor van de dood," 107; and Cort Bericht, tot Voor-cominge ende genesinge vande Peste (Utrecht, 1636), 3.

${ }^{65}$ Noordegraaf and Valk, De gave Gods, 188.

${ }^{66}$ Noordegraaf and Valk, De gave Gods, 195.

${ }^{67}$ Noordegraaf and Valk, De gave Gods, 32-33.

${ }^{68}$ Sheila Barker, "Poussin, Plague, and Early Modern Medicine," Art Bulletin 86, no. 4 (2004): 660.

${ }^{69}$ Barker, "Poussin, Plague," 663.

${ }^{70}$ Jacobus Viverius, De handt Godes of een Christelick verhael vande peste of Gaeve Godes (Delft, 1624), 9; as cited in Noordegraaf and Valk, De gave Gods, 25-26 and 31.

${ }^{71}$ Franco Mormando, "Introduction: Response to the Plague in Early Modern Italy: What the Primary Sources, Print and Painted, Reveal," in Hope and Healing (see note 50 above), 9, 36.

72 Barker, "Poussin, Plague," 663.

${ }^{73}$ Ton Langeveld, "De pest en slachtoffers van de pest in Leiden," Centrum 15, no. 3 (February 15, 1985): 57; and William Swinnas, De pest-stryt, beharnast met veel voor-treffelyke geness-middelen (Leiden, 1664); as cited in Noordegraaf and Valk, De gave Gods, 26, 31.

${ }^{74}$ P. C. Molhuysen and P.J. Blok, Nieuw Nederlandsch Biografisch Woordenboek (Leiden: A. W. Sijthoff, 1912), 2:1500-1501.

${ }^{75}$ Paul Barbette, Pest-Beschryving (Amsterdam, 1655), 11-13.

${ }^{76}$ Rommes, "Op het spoor van de dood," 108.

${ }^{77}$ R. A. Hoogland, "De Cellebroeders," Jaarboek Oud-Utrecht (1974): 184; and W. Moll, Kerkgeschiedenis van Nederland vóór de Hervorming (Arnhem: Nijhoff en Zoon, 1867), 2:161-63.

${ }^{78}$ Moll, Kerkgeschiedenis van Nederland, 2:161-63; and Hoogland, "De Cellebroeders," 184.

${ }^{79}$ Hoogland, "De Cellebroeders," 190; and J. W. C. van Campen, "Leeuwenberch," Jaarboekje van 'Oud-Utrecht' (1931): 82.

${ }^{80}$ Johan de Niet, Ziekentroosters op de pastorale markt, 1550-1880 (Rotterdam: Erasmus, 2006), 33.

${ }^{81}$ A. J. van der Weyde, "Bijdrage tot de geschiedenis der pest te Utrecht," Nederlands Tijschrift voor Geneeskunde 71 (1927): 3132; and Rommes, "Op het spoor van de dood," 99.

${ }^{82}$ Mart van Lieburg, "Religion and Medical Practice in the Netherlands in the Seventeenth Century: An Introduction," in The Task of Healing, Medicine, Religion, and Gender in England and the Netherlands 1450-1800, eds. Hilary Marland and Margaret Pelling (Rotterdam: Erasmus Publishing, 1996), 138-39. 
${ }^{83}$ van der Weyde, "Bijdrage tot de geschiedenis der pest te Utrecht," 3132.

${ }^{84}$ van der Weyde, "Bijdrage tot de geschiedenis der pest te Utrecht," 3132.

${ }^{85}$ Groot Placaatboek vervattende alle de Placaten, ordonnantien en Edicten der Edele Mogende Heeren Staten's Lands van Utrecht (Utrecht, 1729), 516.

${ }^{86}$ Groot Placaatboek, 517-18; and Hoogland, "De Cellebroeders," 184.

${ }^{87}$ Noordegraaf and Valk, De gave Gods, 158.

${ }^{88}$ Joannes Heurnius (1543-1601), Het Noodigh Pestboek (Leiden, 1600); Leo Noordegraaf, "Calvinism and the Plague in the Seventeenth-century Dutch Republic," in Curing and Insuring: Essays on Illness in Past Times, the Netherlands, Belgium, England and Italy, $16^{\text {th }}-20^{\text {th }}$ centuries, eds. Hans Benneveld and Rudolf Dekker (Hilversum: Verloren, 1993), 26.

${ }^{89}$ Mormando, "Introduction," in Hope and Healing (see note 50 above), 23.

${ }_{90}$ Pamela M. Jones, "San Carlo Borromeo and Plague Imagery in Milan and Rome," in Hope and Healing (see note 50 above), 65-96.

${ }^{91}$ Willem Frijhoff, Embodied Belief: Ten Essays on Religious Culture in Dutch History (Hilversum: Verloren, 2002), 118-20.

${ }^{92}$ Parker, Faith on the Margins, 122 and A. Th. van Deursen, Plain Lives in a Golden Age: Popular Culture, Religion, and Society in Seventeenth-Century Holland (Cambridge: Cambridge University Press, 1991), 288.

${ }^{93}$ Noordegraaf, "Calvinism and the Plague," 23, 27.

${ }^{94}$ Noordegraaf and Valk, De gave Gods, 121-22; and Noordegraaf, "Calvinism and the Plague," 21-22.

${ }^{95}$ Simon Oomius, Des Heeren Verderflicke pyl Ofte Tween Boeken vande Pest (Amsterdam, 1665), 131-60.

${ }^{96}$ Noordegraaf, “Calvinism and the Plague," 25.

${ }^{97}$ Philologus Philiatros a Ganda (pseud. J. Viverius), De Wintersche Avonden of Nederlantsche Vertellingen (Amsterdam, 1615), 323-24; as cited in Noordegraaf, "Calvinism and the Plague," 25.

${ }_{98}$ Paul Dijstelberge, "De pest in Bredero's Spaanse Brabander 'De gave Gods," Literatuur 9 (1992): 276; and G. A. Bredero, The Spanish Brabanter: A Seventeenth-Century Dutch Social Satire in Five Acts, trans. H. David Brumble III (Binghamton, N.Y.: Center for Medieval and Early Renaissance Studies, 1982).

${ }^{99}$ King James Bible.

${ }^{100}$ Noordegraaf, "Calvinism and the Plague," 24.

${ }^{101}$ Noordegraaf, "Calvinism and the Plague," 24; and K. Exalto, Beleefd geloof, acht schetsen van gereformeerde theologen uit de 17e eeuw (Amsterdam: Bolland, 1974), 23-26.

${ }^{102}$ Noordegraaf, "Calvinism and the Plague," 24.

${ }^{103}$ King James Bible.

${ }^{104}$ Noordegraaf, "Calvinism and the Plague," 24.

${ }^{105}$ Christine M. Boeckl, Images of Plague and Pestilence: Iconography and Iconology, (Kirksville, Mo.: Truman State University Press, 2000), 54-55, 160-62.

${ }^{106}$ Albert Blankert, Dutch Classicism in Seventeenth-Century Painting, exh. cat. (Rotterdam: Museum Boijmans van Beuningen, and Frankfurt am Main: Städelsches Kunstinstitut/New York: D.A.P., 1999), 132-35; and Paul Dirkse, "Pieter de Grebber: De berouwvole David Kiest uit drie plagen," Catharijnebrief 18 (June 1987): 2-4.

${ }^{107}$ Bourgondische pracht van Philips de Stoute tot Philips de Schone (Haarlem: J. Encschede and Amsterdam: Rijksmuseum, 1951) and Xander van Eck, Clandestine Splendor: Paintings for the 
Catholic Church in the Protestant Dutch Republic (Zwolle: Waanders, 2007), 52.

${ }^{108}$ Joaneath Spicer, with contributions Lynn Federle Orr, Masters of Light: Dutch Painters in Utrecht during the Golden Age (New Haven, Conn.: Yale University Press, 1997), 148, 410.

${ }^{109}$ Seaman, The Religious Paintings of Hendrick ter Brugghen, 71; and Spicer and Orr, Masters of Light, 176-78.

${ }^{110}$ Slatkes and Franits, The Paintings of Hendrick ter Brugghen, 85.

${ }^{111}$ van Eck, Clandestine Splendor, 77, 209 n66.

${ }^{112}$ Esther van Duijn and Jessica Roeders, "Gold-Brocaded Velvets in Paintings by Cornelis Engebrechtsz," Journal of Historians of Netherlandish Art 4, no. 1 (2012): 2-3.

${ }^{113}$ Nigel J. Morgan and Pauline Johnstone, "Vestments, ecclesiastical," Grove Art Online/Oxford Art Online (Oxford: Oxford University Press). Accessed Jan. 3, 2016.

${ }^{114}$ van Eck, Clandestine Splendor, 209.

${ }^{115}$ van Eck, Clandestine Splendor, 77.

${ }^{116}$ I wish to thank the anonymous reviewer who suggested that ter Brugghen's painting may have been commissioned by a local hospital.

${ }^{117}$ Benjamin J. Kaplan, "Confessionalism and Its Limits: Religion in Utrecht, 1600-1650," in Masters of Light, Spicer and Orr, 70; Bok and Kobayashi, "New Data on Hendrick ter Brugghen," 13-14; and Seaman, Religious Paintings of Hendrick ter Brugghen, 63-64, 67.

${ }^{118}$ Benjamin J. Kaplan, Calvinists and Libertines: Confession and Community in Utrecht 1578-1620 (New York: Oxford University Press, 1985), 294.

${ }^{119}$ Kaplan, "Confessionalism and Its Limits," 62; and Kaplan, Calvinists and Libertines, 272-78.

${ }^{120}$ Kaplan, Calvinists and Libertines, 278-79, 278n56.

\section{Bibliography}

Ahl, Diane Cole. Benozzo Gozzoli. New Haven, Conn.: Yale University Press, 1996.

Barbette, Paul. Pest-Beschryving. Amsterdam, 1655.

Barker, Sheila. “The Making of a Plague Saint: Saint Sebastian's Imagery and Cult before the Counter-Reformation." In Piety and Plague: From Byzantium to the Baroque, edited by Franco Mormando and Thomas Worcester, 90-131. Kirksville, Mo.: Truman State University Press, 2007.

Barker, Sheila. "Plague Art in Early Modern Rome: Divine Directives and Temporal Remedies." In Hope and Healing: Painting in Italy in a Time of Plague, 1500-1800, edited by Gauvin Alexander Bailey, Pamela M. Jones, Franco Mormando, and Thomas W. Worchester, 45-64. Chicago: University of Chicago Press, 2005.

Barker, Sheila. "Poussin, Plague, and Early Modern Medicine." Art Bulletin 86, no. 4 (December 2004): 659-89.

Barocchi, Paola. Trattati d'arte del Cinquecento: Fra manierismo e Controriforma. Bari: Gius, Laterza \& Figli, 1961.

Baronius, Caesar. Annales Ecclesiastici. 3 vols. Edited by A. Theiner. Brussels, 1864. 
Blankert, Albert. Dutch Classicism in Seventeenth-Century Painting. Exh. cat. Rotterdam: Museum Boijmans van Beuningen, and Frankfurt am Main: Städelsches Kunstinstitut/New York: D.A.P., 1999.

Blankert, Albert, Leonard J. Slatkes et al., Nieuw licht op de Gouden Eeuw: Henrick ter Brugghen en tijdegenoten. Exh cat. Utrecht: Central Museum, and Braunschweig: Herzog Anton Ulrich-Museum, 1986-87.

Boccardo, Piero, and Xavier F. Salomon, eds. The Agony and the Ecstasy: Guido Reni's St. Sebastians. Milan: Silvana Editoriale, 2007.

Boeckl, Christine M. Images of Plague and Pestilence: Iconography and Iconology. Kirksville, Mo.: Truman State University Press, 2000

Bok, Marten Jan, and Yoriko Kobayashi. “New Data on Hendrick ter Brugghen.” Hoogsteder-Naumann Mercury 1 (1985): 7-34.

Borromeo, Federico. Sacred Painting/Museum. Edited and translated by Kenneth S. Rothwell Jr. Cambridge, Mass.: Harvard University Press, 2010.

Bourgondische pracht van Philips de Stoute tot Philips de Schone. Haarlem: J. Encschede, and Amsterdam: Rijksmuseum, 1951.

Bredero, G. A. The Spanish Brabanter: A Seventeenth-Century Dutch Social Satire in Five Acts. Translated by H. David Brumble III. Binghamton, N.Y.: Center for Medieval and Early Renaissance Studies, 1982.

Campen, J. W. C. van. “Leeuwenberch.” Jaarboekje van 'Oud-Utrecht' (1931): 78-121.

Cordes, Rudolf. Jan Zoet, Amsterdammer 1609-1674: Lleven en Werk van een Kleurrijk Schrijver. Hilversum: Verloren, 2008.

Cort Bericht, tot Voor-cominge ende genesinge vande Peste. Utrecht, 1636.

Cox-Rearick, Janet. “Fra Bartolomeo's St. Mark Evangelist and St. Sebastian with an Angel.” Kunsthistorisches Institut in Florenz 18, no. 3 (1974): 329-54.

Danieli, Francesco. La freccia e la palma. Rome: GAIA Edizioni Universitarie Romane, 2007.

Deursen, A. Th. van. Plain Lives in a Golden Age: Popular Culture, Religion, and Society in Seventeenth-Century Holland. Cambridge: Cambridge University Press, 1991.

Dijstelberge, Paul. "De pest in Bredero's Spaanse Brabander 'De gave Gods.” Literatuur 9 (1992): 273-78. 
Dirkse, Paul. "Pieter de Grebber: De berouwvole David Kiest uit drie plagen.” Catharijnebrief 18 (June 1987): 2-4.

Duijn, Esther van, and Jessica Roeders. "Gold-Brocaded Velvets in Paintings by Cornelis Engebrechtsz." Journal of Historians of Netherlandish Art 4, no. 1 (2012): 1-13.

Eck, Xander van. Clandestine Splendor: Paintings for the Catholic Church in the Protestant Dutch Republic. Zwolle: Waanders, 2007.

Eekelen, F. A. M. van. "Van Geluwe en zijn strijd om de martelaars." Tijdschrift voor Nederlandse Kerkgeschiedenis 14 (June 2011): 60-68.

Exalto, K. Beleefd geloof, acht schetsen van gereformeerde theologen uit de 17e eeuw. Amsterdam: Bolland, 1974.

Franits, Wayne. The Paintings of Dirck van Baburen ca. 1592/93-1624, Catalogue Raisonné. Amsterdam: John Benjamins Publishing, 2013.

Franits, Wayne. "Dirck van Baburen and the "Self-Taught" Master, Angelo Caaroselli." Journal of Historians of Netherlandish Art 5, no. 2 (Summer 2013): 1-12.

Frijhoff, Willem. Embodied Belief: Ten Essays on Religious Culture in Dutch History. Hilversum: Verloren, 2002.

Frijhoff, Willem. "Gods gave afgewezen: Op zoek naar genezing van de pest: Nijmegen, 16351636." Volkskundig Bulletin 17, no. 2 (1991): 143-70.

Gilio, Giovanni Andrea. Dialogo nel Quale si Ragiona degli Errori e degli Abusi de’ Pittori circa l'Istorie. Camerino, 1564.

Groot Placaatboek vervattende alle de Placaten, ordonnantien en Edicten der Edele Mogende Heeren Staten's Lands van Utrecht. Utrecht, 1729.

Henneberg, Josephine von. "Cardinal Caesar Baronius, The Arts, and the Early Christian Martyrs." In Saints and Sinners Caravaggio and the Baroque Image, edited by Franco Mormando, 136-50. Boston: Boston College, McMullen Museum of Art/Chicago: University of Chicago Press, 1999.

Heurnius, Joannes. Het Noodigh Pestboek. Leiden, 1600.

Homer. The Illiad. Translated by Robert Fagles. New York: Penguin Books, 1998.

Hoogland, R. A. “De Cellebroeders.” Jaarboek Oud-Utrecht (1974): 180-92. 
Israel, Jonathan I. The Dutch Republic: Its Rise, Greatness, and Fall 1477-1806. Oxford: Clarendon Press, 1995.

Janssen, Paul Huys. Jan van Bijlert 1597/98-1671 Catalogue Raisonné. Amsterdam: John Benjamins Publishing, 1998.

Jones, Pamela M. "San Carlo Borromeo and Plague Imagery in Milan and Rome" In Hope and Healing, Painting in Italy in a Time of Plague, 1500-1800, edited by Gauvin Alexander Bailey, Pamela M. Jones, Franco Mormando, and Thomas W. Worchester, 65-96. Chicago: University of Chicago Press, 2005.

Judson, J. Richard, and Rudolf E. O. Ekkart. Gerrit van Honthorst 1592-1656. Ghent: Davaco Publishers, 1999.

Kaplan, Benjamin J. Calvinists and Libertines: Confession and Community in Utrecht 1578-1620. New York: Oxford University Press, 1985.

Kaplan, Benjamin J. “Confessionalism and Its Limits: Religion in Utrecht, 1600-1650.” In Masters of Light: Dutch Painters in Utrecht during the Golden Age, Joaneath Spicer with Lynn Federle Orr, 60-71. New Haven, Conn.: Yale University Press, 1997.

Langeveld, Ton. "De pest en slachtoffers van de pest in Leiden." Centrum 15, no. 3 (February 15, 1985): 56-59.

Lieburg, Mart van. "Religion and Medical Practice in the Netherlands in the Seventeenth Century: An Introduction." In The Task of Healing, Medicine, Religion, and Gender in England and the Netherlands 1450-1800, edited by Hilary Marland and Margaret Pelling, 135-44. Rotterdam: Erasmus Publishing, 1996.

Lieburg, M. J. van. "Voetius en de geneeskunde." In De Onbekende Voetius, edited by J. van Oort, 168-80. Kampen: Kok, 1989.

Lightbown, Ronald. Piero della Francesca. New York: Abbeville Press, 1992.

Lomazzo, G. P. Trattato dell'Arte della Pittura. Milan, 1585.

Lowenthal, Anne W. Joachim Wtewael and Dutch Mannerism. Doornspijk: Davaco, 1986.

Machielsen, Jan. "Heretical Saints and Textual Discernment: The Polemical Origins of the Acta Sanctorum (1643-1940)." In Angels of Light? Sanctity and the Discernment of Spirits in the Early Modern Period, edited by Clare Copeland and Jan Machielsen, 103-41. Leiden and Boston: Brill, 2013.

Marchiori, Laura. "Medieval Wall Painting in the Church of Santa Maria in Pallara, Rome: The Use of Objective Dating Criteria." Papers of the British School at Rome 77 (2009): 225-45. 
Marshall, Louise. "Confraternity and Community: Mobilizing the Sacred in Times of Plagues." In Confraternities and the Visual Arts in Renaissance Italy: Ritual, Spectacle, Image, edited by Barbara Wisch and Diane Cole Ahl, 20-45. Cambridge and New York: Cambridge University Press, 2000.

Marshall, Louise. "Manipulating the Sacred: Image and Plague in Renaissance Italy." Renaissance Quarterly 47, no. 3 (Autumn 1994): 485-532.

Moffitt, John F. "Francisco Pacheco and Jerome Nadal: New Light on the Flemish Sources of the Spanish "Picture-within-the-Picture." Art Bulletin 72, no. 4 (December 1990): 631-38.

Moll, W. Kerkgeschiedenis van Nederland vóór de Hervorming. 4 vols. Arnhem: Nijhoff en Zoon, 1867.

Mormando, Franco. "Introduction: Response to the Plague in Early Modern Italy: What the Primary Sources, Print and Painted, Reveal." In Hope and Healing: Painting in Italy in a Time of Plague, 1500-1800, edited by Gauvin Alexander Bailey, Pamela M. Jones, Franco Mormando, and Thomas W. Worchester, 1-44. Chicago: University of Chicago Press, 2005.

Mujica, Barbara. "Healing on the Margins: Ana de San Bartolomé, Convent Nurse." Early Modern Studies Journal 6 (2014): 128-65.

Nickel, Helmut. "The Sun, the Moon, and an Eclipse: Observations on "The Crucifixion with the Virgin and Saint John," by Hendrick Ter Brugghen." Metropolitan Museum Journal 42 (2007): $121-24$.

Niet, Johan de. Ziekentroosters op de pastorale markt, 1550-1880. Rotterdam: Erasmus, 2006.

Noordegraaf, Leo. "Calvinism and the Plague in the Seventeenth-century Dutch Republic," In Curing and Insuring: Essays on Illness in Past Times, the Netherlands, Belgium, England and Italy, $16^{\text {th }}-20^{\text {th }}$ centuries, edited by Hans Benneveld and Rudolf Dekker, 21-31. Hilversum: Verloren, 1993.

Noordegraaf, Leo, and Gerrit Valk. De gave Gods: De pest in Holland vanaf de late Middeleeuwen. Bergen: Octavo, 1988.

Oomius, Simon. Des Heeren Verderflicke pyl Ofte Tween Boeken vande Pest. Amsterdam, 1665.

Parker, Charles H. Faith on the Margins: Catholics and Catholicism in the Dutch Golden Age. Cambridge, Mass.: Harvard University Press, 2008.

Paul the Deacon. History of the Lombards. Translated by William Dudley Foulke, LLD. Edited by Edward Peters. 1907. Reprint. Philadelphia: University of Pennsylvania, 1974.

Philologus Philiatros a Ganda (pseud. Jacobus Viverius). De wintersche avonden of Nederlantsche 
vertellingen. Amsterdam 1615.

Pullapilly, Cyriac K. Caesar Baronius, Counter-Reformation Historian. Notre Dame, Ind.: University of Notre Dame Press, 1975.

Ressouni-Demigneaux, Karim. “The 'Imaginary' Life of Saint Sebastian.” In The Agony and the Ecstasy: Guido Reni's Saint Sebastians, edited by Piero Boccardo and Xavier F. Salomon, 17-31. Milan: Silvana Editoriale, 2007.

Rommes, Ronald. "Op het spoor van de dood, de pest in en rond Utrecht." Jaarboek Oud-Utrecht (1991): 92-120.

Rommes, Ronald. "Pest in perspectief: Aspecten van een gevreesde ziekte in de vroegmoderne tijd.” Tijdschrift voor sociale geschiedenis 16 (1990): 244-66.

Ronen, Avraham. “Gozzoli’s St. Sebastian Altarpiece in San Gimignano." Mitteilungen des Kunsthistorischen Institutes in Florenz 32, no. 1/2 (1988): 77-126.

Roswyde, Heribert. Generale Legende der Heylighen met het leven Jesu Christi ende Marie. Vergadert wt de H. Schrifture, Oude Vaders ende Registers der H. Kercke door P. Petrus Ribadineira, Antwerp, 1649.

Seaman, Natasha T. The Religious Paintings of Hendrick ter Brugghen: Reinventing Christian Painting after the Reformation in Utrecht. Farnham, UK, and Burlington, Vt.: Ashgate, 2012.

Schuckman, Christiaan. "Did Hendrick ter Brugghen Revisit Italy? Notes from an Unknown Manuscript by Cornelis de Bie.” Hoogsteder-Naumann Mercury 4 (1986): 7-22.

Slatkes, Leonard J., and Wayne Franits. The Paintings of Hendrick ter Brugghen 1588-1629, Catalogue Raisonné. Amsterdam: John Benjamins Publishing, 2007.

Smith, Paul, and Carolyn Wilde, eds. A Companion to Art Theory. Oxford and Malden, Mass.: Blackwell Publishing, 2002.

Spear, Richard E. The "Divine" Guido: Religion, Sex, Money and Art in the World of Guido Reni. New Haven, Conn.: Yale University Press, 1997.

Spicer, Joaneath A., with Lynn Federle Orr. Masters of Light: Dutch Painters in Utrecht during the Golden Age. New Haven, Conn.: Yale University Press, 1997.

Swinnas, Willem. De Pest-stryt, beharnast met veel voor-treffelyke geness-middelen verciert met eenige pestaenmerkingen. Leiden, 1664.

Talvacchia, Bette. “The Double Life of St. Sebastian in Renaissance Art." In The Body in Early Modern Italy, edited by Julia L. Hairston and Walter Stephens, 226-48. Baltimore: The Johns Hopkins 
University Press, 2010.

Terry-Fritsch, Allie. "Proof in Pierced Flesh: Caravaggio's Doubting Thomas and the Beholder of Wounds in Early Modern Italy." In Beholding Violence in Medieval and Early Modern Europe, edited by Allie Terry-Fritsch and Erin Felicia Labbie, 15-37. Burlington, Vt.: Ashgate, 2012.

Viverius, Jacobus. De handt Godes of een Christelick verhael vande peste of Gaeve Godes, Delft, 1624.

Weyde, A. J. van der. "Bijdrage tot de geschiedenis der pest te Utrecht." Nederlands Tijschrift voor Geneeskunde 71 (1927): 3119-3139.

Recommended Citation:

Valerie Hedquist, "Ter Brugghen's Saint Sebastian Tended by Irene," Journal of Historians of Netherlandish Art 9:2 (Summer 2017) DOI: 10.5092/jhna.2017.9.2.3. 